\title{
SOIL CONSERVATION SERVICE (SCS) AS A TOOL FOR PROPER DESIGN OF COTTON-FURROW IRRIGATION IN CLAY SOIL
}

\author{
M.A. Aiad(1), M.M.A. Shabana(1)*, I. M. Abdel-Fattah(1) and A.M.I. Meleha ${ }^{(2)}$ \\ (1) Soil, Water and Environment Research Institute, Agricultural Research Center, Giza, \\ Egypt. \\ (2) Water Management Research Institute, National Water Research Center, Egypt. \\ *E-mail: shabanamma@gmail.com
}

Received: Jul. 17, $2019 \quad$ Accepted: Aug. 4, 2019

ABSTRACT: Flood surface irrigation is the main watering system in Egypt and worldwide. Proper design of such system is the milestone for up-grading and improving surface irrigation as for other irrigation systems. In this regard, the said Soil Conservation Service (S.C.S) developed by the soil reclamation bureau, USA was the used tool in the evaluating and assessment of the implemented or the practiced parameters, which executed in cotton furrow irrigation system design in the Northern Nile Delta area. The field trial was conducted during the two growing summer cotton seasons 2017 and 2018 at the experimental farm of Sakha Agricultural Research Station, North Nile Delta area. Combined effects of different land leveling (i.e. traditional, precession (dead level =zero level), 0.05 and $0.10 \%$ ) and irrigation inflow rates. $(2.0,2.7$ and $3.3 \mathrm{Lps} / \mathrm{m}$ widths) were used. The stated treatments were implemented at fixed furrow length and width of $40.0 \mathrm{~m}$ and $0.75 \mathrm{~m}$. respectively. The comparing elements between design created by SCS and the actual practiced measures were: furrow inflow rate (Lps/m), irrigation time (min.), advance time (min.), recession time (min.), opportunity time (min.), depth applied $(\mathrm{mm})$, deep percolation $(\mathrm{mm})$, deep percolation ratio and irrigation application efficiency (IAE).Moreover, extensive economic evaluation was done regarding seed cotton yield, total return, benefit/cost ratio and the specific cost. Analysis of obtained data revealed that application efficiency is acceptable for inflow rate at 2.0 $L p s / m$ width along with precession land leveling of 0.05 or $0.10 \%$, providing the importance of using SCS in design furrow irrigation system in the clayey soils at North Nile Delta. Moreover, maximum water well land productivity were observed under the stated treatment (2.0 Lps/m width with 0.05 or $0.10 \%$ land leveling)

Key words: Furrow irrigation; inflow rate; ground surface leveling; opportunity time; application efficiency; economic evaluation.

\section{INTRODUCTION}

In Egypt, irrigation water management is very important due to the limited water resources which restricted cultivation in the newly reclaimed lands because of current intensive agricultural production which relies heavily on irrigation (Asseng et al., 2018). The agricultural sector consumes more than $84 \%$ of available water resources (El-Beltagy and AboHadeed, 2008). Water supply in Egypt is limited to the average annual share of the
Nile water at Aswan $\left(55.5 \times 10^{9} \mathrm{~m}^{3}\right)$ plus some minor quantities of groundwater and rainfall. Water shortage facing Egypt is continuously increasing and it is prospected to reach the threshold level of the water scarcity of less than $500 \mathrm{~m}^{3}$ $\mathrm{yr}^{-1}$ capita $^{-1}$ (EL-Quosy, 1998). Due to the increase in world population and the increasing need for food and fiber, water demands have increased dramatically (Asseng et al., 2018). This ultimately leads to concerns regarding the reliability 
of the natural water resources and the ability to provide stable; secure; and prosperous life. Improved irrigation management of surface irrigation systems is essential to help in reducing the overall water demand since about three-fourth of the water is being used for irrigation (El-Hendawy et al., 2008). The performance of surface irrigation system highly depends upon the design process, which is related to the appropriateness and precision of land leveling, field shape and dimension, and inflow discharge. Moreover, the irrigation performance also depends on farmer operative decisions, mainly in relation to land leveling maintenance timeliness and time duration of every irrigation event, and water supply uncertainties (Pereira and Trout, 1999, Pereira et al., 2002). Furrow irrigation is widely used because of its low cost and energy requirement (Holzapfel et al., 2010).The pressurized irrigation systems i.e. sprinkler and drip irrigation systems are often more efficient than the furrow irrigation. Therefore, the furrow irrigation system should be designed in such a way to ensure an adequate and uniform water distribution over the field and to minimize the potential water losses. Many researchers in this field have engaged in optimizing the design of furrow irrigation systems to improve irrigation performance which is affected by a range of factors including the inflow discharge, soil infiltration characteristics, field length, required applications volume, cutoff time, surface roughness, and field slope (Pereira and Trout, 1999). The furrow length and application discharge are the main factors affecting application efficiency in design of furrow irrigation in clay soil (Eldeiry et al., 2005, Gillies et al., 2008). The design of border irrigation under different irrigation discharge and cut-off irrigation is reasonably efficient and values of different parameters fall within all the design limitations (Khalifa et al., 2018).

Numerous studies were carried out to enhance irrigation efficiencies to achieve the proper economic use of the water. The good design of gated pipe with precision land leveling improve the water distribution uniformity and save irrigation water by about 12 to $19 \%$ in cotton and wheat respectively (Osman, 2000, Abo Soliman et al., 2008, Abdel Reheem, 2017).

The objective of this investigation was to assess the implemented design of furrow irrigation system comparing with that of SCS under different conditions of land leveling and irrigation discharge regarding the planting irrigation of cotton crop in clay soil at North Nile Delta region. In addition, economic evaluation was taking into consideration.

\section{MATERIALS AND METHODS}

\section{Location of the studied area}

A field experiment was carried out during the two summer seasons of 2017 and 2018 at Sakha Agricultural Research Station which situated at $30^{\circ} 57^{\prime} \mathrm{N}$ latitude $31^{\circ} 07^{\prime} \quad \mathrm{E}$ longitude, with an elevation of about 6 meter above the mean sea level. The soil is clayey in texture; the average values of texture was $19.37 \%$ sand, $27,48 \%$ silt and $53,15 \%$ clay (Table 1). The site represents the circumstances and conditions of Middle North of Nile delta region.

\section{Soil characteristics:}

Soil samples were collected before cultivation of cotton crop from four successive depths: $0-15,15-30,30$ 45 and $45-60 \mathrm{~cm}$, respectively, air dried, grounded, sieved and stored for physiochemical analysis. Mechanical analysis of soil was carried out using the pipette method to obtain soil texture according to Richards (1954) and Jackson (1967). Soil bulk density and total porosity were 
determined using the core sampling technique as described by Campbell, 1994. Infiltration rate was also measured before planting. Soil moisture constants i.e. field capacity (FC) and permanent wilting point (PWP) were determined by using pressure cooker method at 0.33 and 15 atmospheres (Klute, 1986). Soil reaction $(\mathrm{pH})$ was measured in $1: 2.5$ soil water suspension and salinity (EC, $\mathrm{dSm}^{-1}$ ) was also determined in soil paste extract according to Page et al., 1982. Some physical and chemical properties of the experimental soil are shown in Tables 1 and 2.

\section{Experimental layout}

The experiment was designed in a strip block with three replicates where precision different land leveling (i.e.dead level (0.0 level), $0.05 \%, 0.1 \%$ ground surface slope and traditional land leveling) were assigned to main plots, while irrigation discharge (i.e. 2.0, 2.7, and $3.3 \mathrm{I} / \mathrm{sec} / \mathrm{m}$ ) occupied the subplots.

Table 1: Some physical properties of studied soil

\begin{tabular}{|c|c|c|c|c|c|c|c|c|c|c|}
\hline \multirow{2}{*}{$\begin{array}{l}\begin{array}{c}\text { Soil } \\
\text { depth }\end{array} \\
\text { cm }\end{array}$} & \multicolumn{3}{|c|}{$\begin{array}{l}\text { Particle size } \\
\text { distribution } \%\end{array}$} & \multirow[t]{2}{*}{$\begin{array}{c}\text { Texture } \\
\text { grade }\end{array}$} & \multirow{2}{*}{$\begin{array}{c}\text { Basic } \\
\text { infiltration } \\
\text { rate } \\
\mathrm{cm} \mathrm{hr}{ }^{-1}\end{array}$} & \multirow{2}{*}{\begin{tabular}{|c} 
Bulk \\
density \\
Mgm $^{-3}$
\end{tabular}} & \multirow{2}{*}{$\begin{array}{c}\text { Total } \\
\text { porosity } \\
\%\end{array}$} & \multicolumn{3}{|c|}{$\begin{array}{l}\text { Soil moisture } \\
\text { characteristics }\end{array}$} \\
\hline & Sand & Silt & Clay & & & & & FC\% & PWP\% & AW\% \\
\hline $0-15$ & 15.49 & 25.69 & 58.82 & clayey & & 1.16 & 56.23 & 46.5 & 25.1 & 21.4 \\
\hline $15-30$ & 22.5 & 26.19 & 51.31 & clayey & & 1.20 & 54.72 & 39.9 & 21.5 & 18.4 \\
\hline $30-45$ & 18.89 & 29.46 & 51.65 & clayey & & 1,25 & 53.83 & 38.5 & 20.8 & 17.7 \\
\hline $45-60$ & 20.57 & 28.62 & 50.81 & clayey & & 1.30 & 50.94 & 36.4 & 19.6 & 16.8 \\
\hline Mean & 19.37 & 27.48 & 53.15 & clayey & & 1.23 & 53.93 & 40.33 & 21.75 & 18.58 \\
\hline
\end{tabular}

FC: Field capacity, \%; PWP: Permanent wilting point, $\%$ AW: available water, $\%$

Table 2 : Some chemical properties of the studied soil

\begin{tabular}{|c|c|c|c|c|c|c|c|c|c|c|}
\hline \multirow{2}{*}{$\begin{array}{c}\text { Soil } \\
\text { depth, } \\
\text { cm }\end{array}$} & \multirow{2}{*}{$\begin{array}{c}\mathrm{EC}^{*} \\
\mathrm{dSm^{-1 }}\end{array}$} & \multicolumn{4}{|c|}{ Soluble Cations Cmol L-1 } & \multicolumn{4}{|c|}{ Soluble anions $\mathrm{Cmol} \mathrm{L}^{-1}$} & \multirow{2}{*}{$\mathrm{pH}^{* *}$} \\
\hline & & $\mathrm{Ca}^{++}$ & $\mathbf{M g}^{++}$ & $\mathrm{Na}^{+}$ & $\mathrm{K}^{+}$ & $\mathrm{CO}^{--}$ & $\mathrm{HCO}^{-}$ & $\mathrm{Cl}^{-}$ & so4-- & \\
\hline $0-15$ & 2.0 & 4.0 & 2.0 & 14.8 & 0.1 & - & 3.5 & 5.5 & 11.9 & 8.26 \\
\hline $15-30$ & 2.2 & 4.0 & 2.5 & 15.0 & 0.2 & - & 3.5 & 5.5 & 12.7 & 8.00 \\
\hline $30-45$ & 2.3 & 4.2 & 2.3 & 16.0 & 0.2 & $\ldots$ & 3.3 & 5.8 & 13.6 & 8.35 \\
\hline $45-60$ & 2.6 & 4.5 & 2.5 & 18.2 & 0.2 & - & 3.0 & 6.5 & 15.9 & 8.40 \\
\hline Mean & 2.28 & 4.18 & 2.33 & 16.0 & 0.18 & - & 3.33 & 5.83 & 13.53 & \\
\hline
\end{tabular}

* EC was determined in saturated soil paste extract.

${ }^{* *} \mathrm{pH}$ was determined in soil water suspension (1:2.5). 


\section{Description of gated pipes:}

The specification of the used gated aluminum pipes was 6 meter length, 152 $\mathrm{mm}$ inner diameter, and $37 \mathrm{~mm}$ orifice diameter as well as the distance between each two adjacent orifices is $0.75 \mathrm{~m}$ and the average operation pressure head ranging from 35 to $50 \mathrm{~cm}$.

\section{Agronomic practices}

Cotton Giza 86 variety was used, and seeds were sown on April 10, 2017 and picked on Sep.20, 2017.while in the second season, the dates of planting and harvesting were april,15,2018 and sep,25,2018, respectively. The different agricultural practices were performed as recommended in the area.

\section{Field trial layout}

Cotton was planted in strips, each strip contains 8 furrow, length of each furrow was $\mathbf{4 0} \mathrm{m}$ and its width was $\mathbf{0 . 7 5}$ $\mathrm{m}$, so the area of each irrigation strip was $240 \mathrm{~m}^{2}$ (0.024 ha)

\section{Hydraulic relationships}

The used hydraulic relationships are basically those developed by the Soil Conservation Service (USDA., 1974 and USDA., 1979). These relationships rely on the infiltration concepts. Infiltration constants are required for design surface irrigation systems. These constants are listed for each intake family. The intake constants are for depth of infiltration in $\mathrm{mm}$, whereas the corresponding constants were for the depth in inch.

The equations of furrow irrigation system design could be presented as described by EWUP Technical Report No.35 (1983) as follows:

SO $=0.0875$ QF ${ }^{0.5419} / \mathrm{L}$

Where:

SO: slope $(\mathrm{m} / \mathrm{m})$

QF: flow rate (L/sec)

$L$ : furrow length

$\mathrm{P}+\mathrm{K}=0.2647\left(\mathrm{QFn} / \mathrm{SO}^{0.5}\right)^{0.4247}+0.2274 \ldots$ (2)
Where:

$P+K$ : wetted perimeter of furrow $(m)$

$P=$ adjusted wetted perimeter $(m)$

$\mathrm{n}$ : surface roughness, $\mathrm{n}$ (usually 0.04 )

$\operatorname{Tn}=\left(\frac{\frac{W}{P+K} D u-c}{a}\right)^{\frac{1}{b}}$

Where:

$\mathrm{Tn}=$ net infiltration time $(\mathrm{min}$.

$W=$ furrow spacing $(m)$

$a, b$ and $c$ : are function parameters

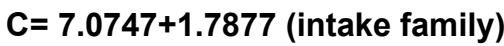

Du: the desired net depth of infiltrated water

$T a=\frac{P L}{60 Q F}\left(a T^{b} o a+6.985\right)$

where:

Ta: Irrigation time (min)

Toa: opportunity time (min.)

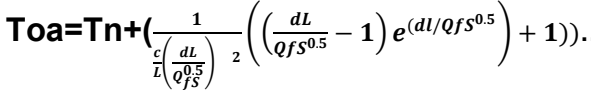

Where:

d: $9.2493 \times 10^{-5}+3.263 \times 10^{-4} \mathrm{IF}$

$\mathrm{Tt}=\frac{L}{C} e^{\left(\frac{d l}{Q f s^{0.5}}\right)}$

Where:

Tt: advance time $(\min )$

$\mathrm{Da}=\frac{60 Q F T a}{W L}$

Where:

Da: depth applied in $(\mathrm{mm})$

$\mathrm{DP}=\mathrm{Da}-\mathrm{Du}$

Where:

DP: deep percolation $(\mathrm{mm})$

$D_{a}$ : depth applied in $(\mathrm{mm})$

Du: net desired depth infiltrated $(\mathrm{mm})$

Deep percolation ratio: $\frac{D P}{D a}$.

Where:

DP: deep percolation $(\mathrm{mm})$

Da: depth applied $(\mathrm{mm})$

$\mathrm{Ea}=\frac{D a u}{D a}$.

Where:

Ea: application efficiency, \%

Dau: desired depth of infiltration ( $\mathrm{mm}$ )

\section{Amount of water applied:}

The discharge through an orifice was determined from the following equation as described by Brater and King, 1976: 
$\mathrm{Q}=\mathrm{CA}(2 \mathrm{GY})^{1 / 2}$

Where:

$\mathrm{Q}=$ Discharge rate, $\mathrm{m}^{3} \mathrm{sce}^{-1}$,

$C=$ discharge coefficient ranges from 0.6 to 0.8

$A=$ area of orifice opening $\left(\mathrm{m}^{2}\right)$

$\mathrm{G}=$ accelerating of gravity $\left(9.8 \mathrm{msec}^{-2}\right)$

$Y=$ The head causing free flow where $Y$ is the upstream head measured from the center of orifice opening.

\section{Water consumptive use (CU):}

Was calculated using the equation of Israelson and Hansen (1962).

10. Water productivity (WP).

It was calculated by the following equation according to Abd EI -Rasool et al. (1971).

C.W.U .E. $=\frac{\text { Yield }\left(\mathrm{Kg} \mathrm{fed}^{-1}\right)}{\text { Water consumptive use }\left(\mathrm{m}^{3} \mathrm{fed}^{-1}\right)}$

\section{Productivity of irrigation water} (PIW).

It was calculated in $\mathrm{Kg} \mathrm{m}^{-3}$ for different irrigation systems to clarify how much $\mathrm{Kg}$ yield is produced from one cubic meter applied (Michael,1978)

\section{Evaluation of furrow irrigation}

The evaluation of furrow irrigation was calculated according to equation described by James, 1988 as follows:

$\mathrm{RZ}=\mathrm{D}(\Theta \mathrm{fc}-\Theta \mathrm{m}) / \mathbf{1 0 0}=$ Wa- Dp-Ro......(12)

$\mathbf{W a}=\mathbf{Q t} / \mathbf{A}$

where:

$\mathrm{Rz}=$ Amount of stored water in the effective root zone $(m)$.

$\mathrm{Wa}=$ total water applied $(\mathrm{cm})$

$\Theta$ fc and $\Theta m=$ volumetric water contents in percent at field capacity and prior to irrigation respectively.

$Q=$ average stream size during the irrigation $\left(\mathrm{m}^{3} / \mathrm{min}\right)$

$t=$ duration of irrigation (min.)

$\mathrm{Dp}=$ Deep percolation $(\mathrm{cm})$

$\mathrm{R} 0=$ Run off $(\mathrm{cm})$.

$A=$ average irrigated area $\left(\mathrm{m}^{2}\right)$

R0 $=$ Wa-D', where:

$D^{-}=$calculated infiltrated depth $(\mathrm{cm})$

$\mathrm{DZ}=\theta \mathrm{fc}-\theta \mathrm{m}$,

where:

$D Z=$ depth to fill root zone $(m)$ (required depth)

Ofc $=$ moisture percent at field capacity

$\theta \mathrm{m}=$ moisture percent before irrigation

$D P=D-D z$

Infiltrated depth (cm) was calculated through coefficient of linear regression between elapsed time (minutes) and cumulative infiltrated depth using the modified kostiakov's equation (Gillies and Smith, 2005) as follows:

$\mathrm{Z}=\mathrm{a} \mathrm{T}^{\mathrm{b}}$

where, $Z=$ calculated infiltrated depth, $\mathrm{cm}, \mathrm{T}=$ opportunity intake time (min.), a= slope of line, and $b=$ intercept.

Irrigation application efficiency (IAE, $\%)$ was calculated by dividing the volume of water stored in the effective root zone with the applied irrigation water (Downy, 1970) as follows:

$I A E=(D a-(D p+R 0) / D a \times 100$

where:

$\mathrm{Da}=$ application water $(\mathrm{cm}), \mathrm{Dp}=$ deep percolation $(\mathrm{cm}), \mathbf{R o}=$ Runoff $(\mathrm{cm})$.

\section{Economic evaluation:}

Cash inflow and outflows for various treatments (as price of the local market) were calculated, and some economic indicators were also estimated such as:

1-Net return, which calculated by deducting the total cost from the total return, (LE/fed)

2- Benefit -cost ratio (BCR), calculated by dividing the total seasonal return by total seasonal cost (Atiea, 1986).

\section{RESULTS AND DISCUSSION}

1. Amount of irrigation water applied:

The average amount of irrigation water delivered to each treatment is presented of table 3 . The ground surface slope $0.1 \%$ decreased the amount of water applied and slope $0.05 \%$ compared 
M.A. Aiad, et al.,

to traditional land leveling. Also, irrigation water discharge at $3.3 \mathrm{Lps} / \mathrm{m}$ is the less amount of water applied compared with 2.0 and $2.7 \mathrm{Lps} / \mathrm{m}$. it is clear from data obtained that the water requirements for cotton plant ranged between (2675 to $\left.4495 \mathrm{~m}^{2} \mathrm{fed}^{-1}\right)$. The lowest values were recorded from irrigation water discharge $3.3 \mathrm{Lps} / \mathrm{m}$ $\left(2675 \mathrm{~m}^{3} \mathrm{fed}^{-1}\right)$ under $0.1 \%$ ground surface slope. While, the highest value is obtained from irrigation water discharge $2 \mathrm{Lps} / \mathrm{m}$ was (4495 $\left.\mathrm{m}^{3} \mathrm{fed}^{-1}\right)$ and traditional land leveling. The results indicated that the $0.1 \%$ and $0.05 \%$ ground surface slope saved irrigation water by $33.57 \%$ and $21.93 \%$ compared to traditional land leveling. The results are in harmony with those obtained by Elmowlhi et al. (1995), El-Shahawy (2004).

\section{Water consumptive use.}

Data in Table 3 show that the mean values of water consumptive use were decreased with ground surface slope 0.1 $\%$ and $\mathbf{0 . 0 5 \%}$.the highest mean value of WCU $\left(2696 \mathrm{~m}^{3} \mathrm{fed}^{-1}\right)$ was recorded under traditional land leveling. On the other hand, the lowest mean value $\left(2206 \mathrm{~m}^{3}\right.$ fed $^{-1}$ ) was recorded under ground surface slope $0.1 \%$. Generally, seasonal water consumptive use decreased as soil available water amount decreased. The results are in friendship with those found by El-mowlhi et al. (1995), El-Shahawy (2004) and Hassan and Elwan (2016).

Table 3: Effect of land leveling and irrigation water discharge on water applied, water consumptive use, Water productivity and productivity of irrigation water (average of two seasons).

\begin{tabular}{|c|c|c|c|c|c|c|}
\hline \multicolumn{2}{|c|}{ Treatments } & \multirow{2}{*}{$\begin{array}{c}\text { Seed } \\
\text { cotton } \\
\text { yield } \\
\text { Kg fed }^{-1}\end{array}$} & \multirow{2}{*}{$\begin{array}{c}\text { water } \\
\text { applied } \\
\text { m }^{3} \text { fed }^{-1}\end{array}$} & \multirow{2}{*}{$\begin{array}{c}\text { water } \\
\text { consumptive } \\
\text { use } \\
\mathrm{m}^{3} \mathrm{fed}^{-1} \\
\end{array}$} & \multirow{2}{*}{$\begin{array}{c}\text { Water } \\
\text { productivity } \\
\mathrm{Kg} \mathrm{m}^{-3}\end{array}$} & \multirow{2}{*}{$\begin{array}{c}\text { productivity } \\
\text { of irrigation } \\
\text { water } \\
\mathrm{Kg} \mathrm{m}^{-3}\end{array}$} \\
\hline $\begin{array}{c}\text { Land } \\
\text { leveling }\end{array}$ & $\begin{array}{l}\text { Irrigation } \\
\text { discharge }\end{array}$ & & & & & \\
\hline \multirow{4}{*}{ Traditional } & 2.0 & 1381.3 & 4495 & 2721 & 0.51 & 0.31 \\
\hline & 2.7 & 1515.2 & 4210 & 2690 & 0.56 & 0.36 \\
\hline & 3.3 & 1419.1 & 4152 & 2677 & 0.53 & 0.34 \\
\hline & Mean & 1438.5 & 4285.7 & 2696.0 & 0.53 & 0.34 \\
\hline \multirow{4}{*}{$\begin{array}{c}\text { Precision } \\
\text { land } \\
\text { leveling }\end{array}$} & 2.0 & 1434.83 & 3775 & 2681 & 0.54 & 0.38 \\
\hline & 2.7 & 1638 & 3582 & 2665 & 0.61 & 0.46 \\
\hline & 3.3 & 1464.8 & 3392 & 2612 & 0.56 & 0.43 \\
\hline & Mean & 1512.5 & 3583.0 & 2652.7 & 0.57 & 0.42 \\
\hline \multirow{4}{*}{$\begin{array}{c}0.05 \% \\
\text { ground } \\
\text { surface } \\
\text { slope }\end{array}$} & 2.0 & 1568.7 & 3498 & 2590 & 0.61 & 0.45 \\
\hline & 2.7 & 1735.7 & 3341 & 2564 & 0.68 & 0.52 \\
\hline & 3.3 & 1661.63 & 3198 & 2402 & 0.69 & 0.52 \\
\hline & Mean & 1655.3 & 3345.7 & 2518.7 & 0.66 & 0.49 \\
\hline \multirow{4}{*}{$\begin{array}{c}0.1 \% \\
\text { ground } \\
\text { surface } \\
\text { slope }\end{array}$} & 2.0 & 1638 & 3042 & 2249 & 0.73 & 0.54 \\
\hline & 2.7 & 1831.73 & 2825 & 2194 & 0.83 & 0.65 \\
\hline & 3.3 & 1784.5 & 2675 & 2175 & 0.82 & 0.67 \\
\hline & Mean & 1751.4 & 2847.3 & 2206.0 & 0.79 & 0.62 \\
\hline
\end{tabular}


3. Water productivity (WP) and productivity of irrigation water (PIW).

Data in Table 3 show the different land leveling and irrigation water discharge on water productivity and productivity of irrigation water. The mean values for WP and PIW were increased under ground surface slope at $0.1 \%$ and $0.05 \%$ and irrigation discharge at $3.3 \mathrm{Lps} / \mathrm{m}$. the increasing for WP and PIW might be due to the decreased in the amount of water consumption use and water applied under traditional land leveling and irrigation water discharge at $2 \mathrm{Lps} / \mathrm{m}$, respectively.

\section{Intake characteristics of North} Nile Delta soils:

Infiltration is generally defined as the process of water entry into the soil profile. The study and characterization of infiltration is of upmost important irrigation. For design and evaluation purposes, it is necessary to know the rate at which water enters the soil and the amount which can be held in the profile before runoff and lor deep percolation begins. Soil infiltration capacities and rates are required data before irrigation designs or modifications can be formulated which will result in good uniformity and efficiently applied water. This especially true for surface irrigation methods. For border or basin irrigation, infiltration is generally assumed to occur vertically downward cone dimensional and affected by the shape of the infiltration surface which affects the rate of water entry, as in furrow irrigation, this rate is more commonly termed intake rate. Most well drained soils will generally exhibit an initially high infiltration rate which decreases with time and eventually approaches a constant rate. This process of decreasing capillary pressure gradient resulted from a deepening wetting front. Several tests have been conducted to determine the range of infiltration characteristics of Sakha soils in the two growing seasons of 2017 and 2018 as shown in Table 4 and illustrated in Fig.1.

Table 4: Infiltration rate $\left(\mathrm{cm} \mathrm{hr}^{-1}\right)$ and cumulative infiltrated depth $(\mathrm{cm})$ before planting irrigation of cotton crop in seasons 2017 and 2018.

\begin{tabular}{|c|c|c|c|c|}
\hline \multirow{2}{*}{$\begin{array}{c}\text { Elapsed } \\
\text { time } \\
(\text { min. })\end{array}$} & \multicolumn{2}{|c|}{ first season, 2017} & \multicolumn{2}{c|}{ second season, 2018 } \\
\cline { 2 - 5 } & $\begin{array}{c}\text { Infiltration rate } \\
\left(\mathrm{cm} \mathrm{hr}^{-1}\right)\end{array}$ & $\begin{array}{c}\text { Cumulative } \\
\text { infiltrated depth } \\
(\mathrm{cm})\end{array}$ & $\begin{array}{c}\text { Infiltration } \\
\text { rate }\left(\mathrm{cm} \mathrm{hr}^{-1}\right)\end{array}$ & $\begin{array}{c}\text { Cumulative } \\
\text { infiltrated depth } \\
\text { (cm) }\end{array}$ \\
\hline 5 & 15.6 & 1.3 & 12.0 & 1.0 \\
\hline 10 & 10.8 & 2.2 & 7.2 & 1.6 \\
\hline 20 & 5.4 & 3.1 & 4.8 & 2.4 \\
\hline 30 & 4.8 & 3.9 & 4.2 & 3.1 \\
\hline 45 & 3.2 & 4.7 & 2.8 & 3.8 \\
\hline 60 & 2.0 & 5.2 & 2.4 & 4.4 \\
\hline 90 & 1.8 & 6.1 & 1.8 & 5.3 \\
\hline 120 & 1.4 & 6.8 & 1.6 & 6.1 \\
\hline 180 & 1.4 & 8.2 & 1.3 & 7.4 \\
\hline
\end{tabular}


M.A. Aiad, et al.,

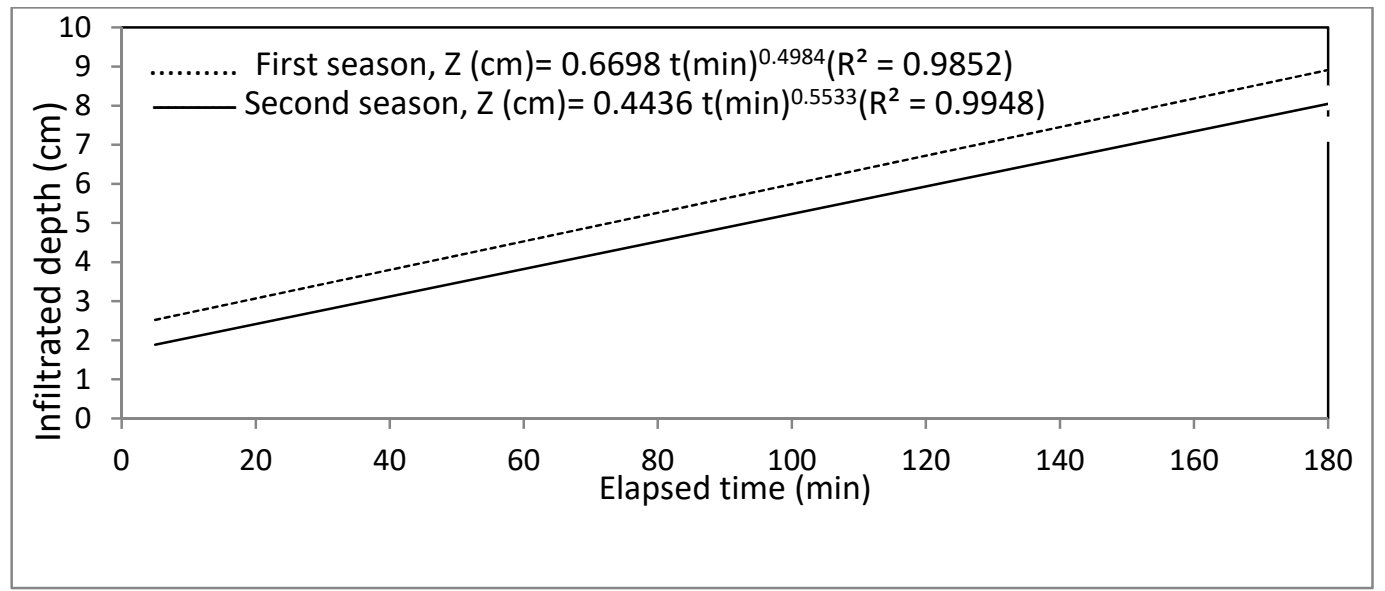

Fig. 1: Regression curves for infltration and Intake functions for planting irrigation of cotton crop during the first and second seasons.

The rate at which a soil absorbs water usually decreases rather rapidly with time after several hours however it usually becomes nearly constant. This is called the basic infiltration rate (Garcia, 1978). The infiltration rate and cumulative infiltration values before planting irrigation of cotton crop in the first and second seasons is presented in Table 4. and Fig.1.

As noticed, infiltration rate decreased rapidly from $15.6 \mathrm{~cm} \mathrm{hr}^{-1}$ to $1.4 \mathrm{~cm} \mathrm{hr}^{-1}$ and from $12 \mathrm{~cm} \mathrm{hr}^{-1}$ to $1.3 \mathrm{cmhr}^{-1}$ in the first and second seasons respectively. While values of the cumulative infiltrated depth were 8.2 and $7.4 \mathrm{~cm}$ at 3 hours elapsed time in the first and second seasons, respectively.

\section{Infiltration function.}

The data of the infiltration functions were subjected to a fitting regression curve to determine the best fit regression coefficient in a power function of the form:

$$
\mathrm{Z}=\mathbf{a} \mathrm{T}^{\mathrm{b}}
$$

This is simple and well-known as empirical infiltration function of the modified Kostiakov equation (e.g., Walker, 2005 and Gillies and Smith, 2005) form, where $Z$ is the accumulated infiltrated depth $(\mathrm{cm}), T$ is the elapsed time (minutes), and a (cm/ $\left.\mathrm{min}^{\mathrm{b}}\right)$ and $b$ (dimensionless) are empirical coefficients. Available test data for planting irrigation in both seasons were analyzed using a curve fitting regression. The results of individual regressions are illustrated in Figure 1. The tests conducted with the planting irrigation in both seasons are considered representative for the soil intake conditions.

\section{Soil intake family}

The United States Soil Conservation Service (SCS) has conducted many field trails to measure and categorize infiltration rates. The SCS has used a slightly modified form of the kostiakov equation to represent infiltration. Application of this method has been aided by use of the intake family concept. The governing equation for infiltration using the SCS method is given by:

$i=a(t){ }^{b}+c$ in which $i$ and $t$ are depth of infiltration, $\mathrm{cm}$ and time of infiltration, $\min$ and $a \& b$ are given as a function of intake family which varies depending on whether is determined in inches or centimeters, and $b$ are listed for different intake families in Table 5. With reference to the SCS procedures for level 
furrow (USDA., 1979), irrigation designs and the SCS method for classifying soils into intake families the following comments are made concerning the results in Table 5. The results for the first and the second seasons of cotton crop considered representative of the soil infiltration characteristics at planting irrigation and would be equivalent to 0.55 and 0.51 intake families.

\section{Uniformity coefficient of water} applied:

The uniformity of applied water is a convenient way to judge the performance of irrigation methods. High values of water distribution uniformity at different sections of the field mean received similar application depths. In Table 6 indicates the levels of uniformity. It is noted that calculated uniformity levels for different of both land leveling methods and irrigation water discharge usually more than 0.9 . The uniformity coefficient values were found to be $0.98,0.99,0.99$ and 0.99 for traditional land leveling, precision land leveling $0.05 \%$ and $0.1 \%$ ground surface slope respectively in the first season. While that values were slightly lower to be $0.92,0.98,0,98$ and 0.98 for the stated treatments in the second season. The highest values of uniformity coefficient were obtained with 2.7 LPs/ $\mathrm{m}$ as irrigation discharge under $0.05 \%$ slope or $0.1 \%$ slope in the first and second seasons, respectively. Generally, uniformity coefficient above 0.9 is considered as suitable value, thus the designs formulated gave very acceptable levels of uniformity. The effects of different land leveling and irrigation discharge plus the nature of the soil in the area contributed to the good results in Table 6.

Table 5: Intake family and advance coefficients for infiltration depth in $\mathrm{mm}$, time in minutes and length in meters.

\begin{tabular}{|c|c|c|c|c|c|}
\hline intake family & a & b & c & f & g \\
\hline 0.05 & 0.5334 & 0.618 & 7.0 & 7.16 & $1.088 \times 10^{-4}$ \\
\hline 0.1 & 0.6198 & 0.661 & 7.0 & 7.25 & $1.251 \times 10^{-4}$ \\
\hline 0.15 & 0.711 & 0.683 & 7.0 & 7.34 & $1.414 \times 10^{-4}$ \\
\hline 0.2 & 0.7772 & 0.699 & 7.0 & 7.43 & $1.578 \times 10^{-4}$ \\
\hline 0.25 & 0.8534 & 0.711 & 7.0 & 7.52 & $1.741 \times 10^{-4}$ \\
\hline 0.3 & 0.9246 & 0.72 & 7.0 & 7.61 & $1.904 \times 10^{-4}$ \\
\hline 0.35 & 0.9957 & 0.729 & 7.0 & 7.7 & $2.067 \times 10^{-4}$ \\
\hline 0.4 & 1.064 & 0.736 & 7.0 & 7.79 & $2.23 \times 10^{-4}$ \\
\hline 0.45 & 1.13 & 0.742 & 7.0 & 7.88 & $2.393 \times 10^{-4}$ \\
\hline 0.5 & 1.196 & 0.748 & 7.0 & 7.97 & $2.556 \times 10^{-4}$ \\
\hline 0.6 & 1.321 & 0.757 & 7.0 & 8.15 & $2.883 \times 10^{-4}$ \\
\hline 0.7 & 1.443 & 0.766 & 7.0 & 8.33 & $3.209 \times 10^{-4}$ \\
\hline 0.8 & 1.56 & 0.773 & 7.0 & 8.5 & $3.535 \times 10^{-4}$ \\
\hline 0.9 & 1.674 & 0.779 & 7.0 & 8.68 & $3.862 \times 10^{-4}$ \\
\hline 1.0 & 1.786 & 0.785 & 7.0 & 8.86 & $4.188 \times 10^{-4}$ \\
\hline 1.5 & 2.284 & 0.799 & 7.0 & 9.76 & $5.819 \times 10^{-4}$ \\
\hline 2.0 & 2.753 & 0.808 & 7.0 & 10.65 & $7.451 \times 10^{-4}$ \\
\hline
\end{tabular}


M.A. Aiad, et al.,

Table 6: Soil Conservation Service (SCS) intake family and application uniformity (UCH) for the different treatments in planting irrigation during the two growing seasons of cotton crop.

\begin{tabular}{|c|c|c|c|c|c|}
\hline \multicolumn{2}{|c|}{ treatments } & \multicolumn{2}{|c|}{ first season } & \multicolumn{2}{|c|}{ second season } \\
\hline $\begin{array}{l}\text { land } \\
\text { leveling }\end{array}$ & $\begin{array}{c}\text { irrigation } \\
\text { discharge } \\
\text { Lps/m }\end{array}$ & $\begin{array}{l}\text { SC's intake } \\
\text { family }\end{array}$ & $\begin{array}{c}\text { application } \\
\text { uniformity }\end{array}$ & $\begin{array}{l}\text { SC's intake } \\
\text { family }\end{array}$ & $\begin{array}{l}\text { application } \\
\text { uniformity }\end{array}$ \\
\hline \multirow{3}{*}{ traditional } & 2 & 0.55 & 0.966 & 0.51 & 0.832 \\
\hline & 2.7 & 0.55 & 0.972 & 0.51 & 0.970 \\
\hline & 3.3 & 0.55 & 0.988 & 0.51 & 0.970 \\
\hline \multicolumn{2}{|c|}{ (mean) } & 0.55 & 0.975 & 0.51 & 0.924 \\
\hline \multirow{3}{*}{$\begin{array}{l}\text { precision } \\
\text { land } \\
\text { leveling }\end{array}$} & 2 & 0.55 & 0.992 & 0.51 & 0.972 \\
\hline & 2.7 & 0.55 & 0.980 & 0.51 & 0.987 \\
\hline & 3.3 & 0.55 & 0.997 & 0.51 & 0.973 \\
\hline \multicolumn{2}{|c|}{ (mean) } & 0.55 & 0.990 & 0.51 & 0.977 \\
\hline \multirow{3}{*}{$\begin{array}{c}0.05 \% \\
\text { ground } \\
\text { surface } \\
\text { slope }\end{array}$} & 2 & 0.55 & 0.989 & 0.51 & 0.981 \\
\hline & 2.7 & 0.55 & 0.986 & 0.51 & 0.985 \\
\hline & 3.3 & 0.55 & 0.984 & 0.51 & 0.983 \\
\hline \multicolumn{2}{|c|}{ (mean) } & 0.55 & 0.986 & 0.51 & 0.983 \\
\hline \multirow{3}{*}{$\begin{array}{c}0.1 \% \\
\text { ground } \\
\text { surface } \\
\text { slope }\end{array}$} & 2 & 0.55 & 0.981 & 0.51 & 0.977 \\
\hline & 2.7 & 0.55 & 0.990 & 0.51 & 0.981 \\
\hline & 3.3 & 0.55 & 0.990 & 0.51 & 0.983 \\
\hline \multicolumn{2}{|c|}{ (me } & 0.55 & 0.987 & 0.51 & 0.980 \\
\hline
\end{tabular}

8. Level furrow design under different land leveling and irrigation water discharge:

In level furrow design, the designer usually seeks to find the inflow rate for each furrow based on the input design conditions such as an acceptable irrigation time and application efficiency resulted. Sometimes the irrigation time is also specified, and some compromise between a reduction in losses at the upper part of the field under irrigation and at the lower end is necessary. The SCS level furrow design model calls for the following input design parameters:

1-furrow length, 2-furrow spacing, 3SCS intake family and intake function parameters, 4-design requirements depth, 5 -manning's $\mathbf{n}$ value (commonly $\mathbf{n}$ $=0.04$ for furrow design). $A$ range of possible furrow inflow rates should be tested under different land leveling.

Flow rates too low will result in excessive water advanced times and poor performance. Flow rates too high will cause erosion in the furrow and over topping of the furrow design. Site specific conditions will generally constrain the range of possible trial rates. The large the stream is, however, the better the performance will be. Also, for a given discharge, the uniformity of application varies inversely with intake rate; better uniformity with lower intake 
and vice versa. Thus, for level furrow irrigation the furrow must be large deep and well-made.

Good tillage and maintenance of furrow cross-section through the season is strongly recommended. For each trial furrow stream the model will determine the required application time, estimated advance time, furrow wetted perimeter, the depth applied, the deep percolation and the application efficiency. Therefore, the designer chooses the furrow inflow rate which best meets this and is within site specific constraints. With the total available flow at the filed inlet known, the designer could determine the number of furrows which can be irrigated in one set.

\section{Effect of design parameters variation:}

An irrigation system is usually designed to supply the crop water requirements during some peak use period. Typically, such design may be based on the design conditions (i.e, design parameters values) at the time of the peak use period. The variation of the design parameters over time is an important consideration which is often neglected. The designer must be aware of the effects of design parameters variation on system performance to formulate an effective design and to develop appropriate system management recommendations. For level furrow design, the analyses were for effects of change in furrow inflow rate, roughness, design applied depth for planting irrigation of cotton crop in the first and second seasons as shown in Tables 7 and 8 . Since best designs are formulated, the inflow time usually also varied with changes in other parameters. The general determined trends were:

- Application efficiency is acceptable for furrow inflow rate at $2 \mathrm{~L} \mathrm{Sec}^{-1} \mathrm{~m}^{-1}$ width. For inflow rates less than $2 \mathrm{Lps} / \mathrm{m}$, inflow times are excessive.
-The lowest value of deep percolation and deep percolation ratio were achieved with inflow rate at $2 \mathrm{Lps} / \mathrm{m}$.

-The data indicated that as inflow rate increase, the net infiltration time, advance time and opportunity time were decreased.

In this concern, (Amer, 2011, ELHadidi et al., 2016, Salahou et al., 2018), reported that the method is best suited for medium to low intake rate soils which can be used for irrigating all crops. Proper design of level irrigation systems (basin dimensions, number of furrows which can be irrigated depends on the water supply flow rate) soil infiltration characteristics and other factors.

\section{Evaluation of the design:}

Based on the best attained values from the field experiment under different land leveling and irrigation discharge, mathematical equation was developed to check the design and to determine if the assumptions used in formulating the design were correct or not. The equation was then executed to determine the system calculation performance through the design limitations. The output design limitations of the furrow system were; irrigation time, advance time, recession time, opportunity time advance ratio, depth applied, deep percolation ratio and application efficiency. Data of tables 9-12 show the comparison of measured and design conditions of furrow irrigation under different land leveling and irrigation discharge in planting irrigation of cotton crop in the first and second seasons, respectively. The evaluation results for planting irrigation of cotton crop could be summarized as follows:

\subsection{Irrigation time:}

The design irrigation time was lower than the measured one under different treatments. At the same time, the highest value of irrigation time was recorded 


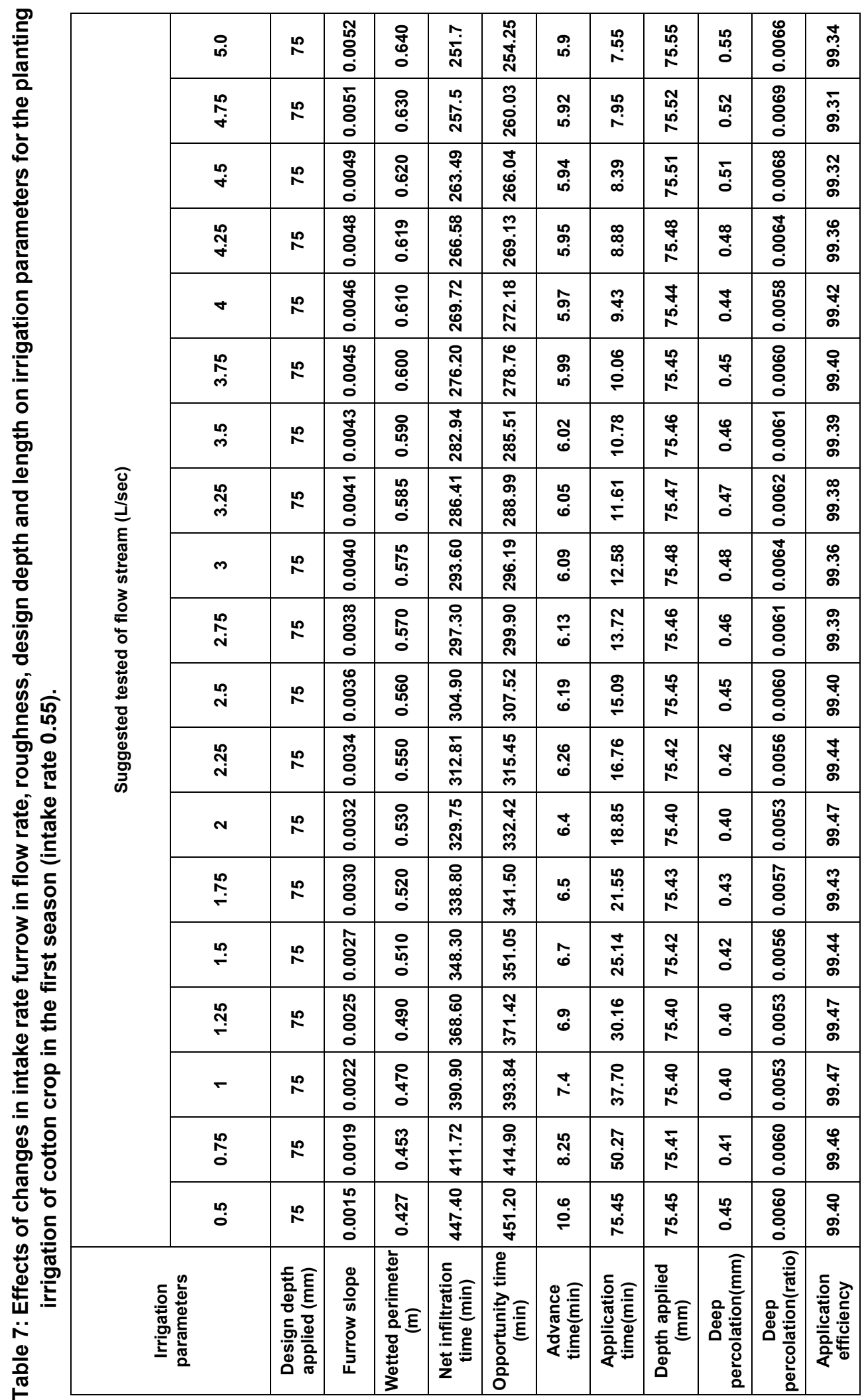


M.A. Aiad, et al.,

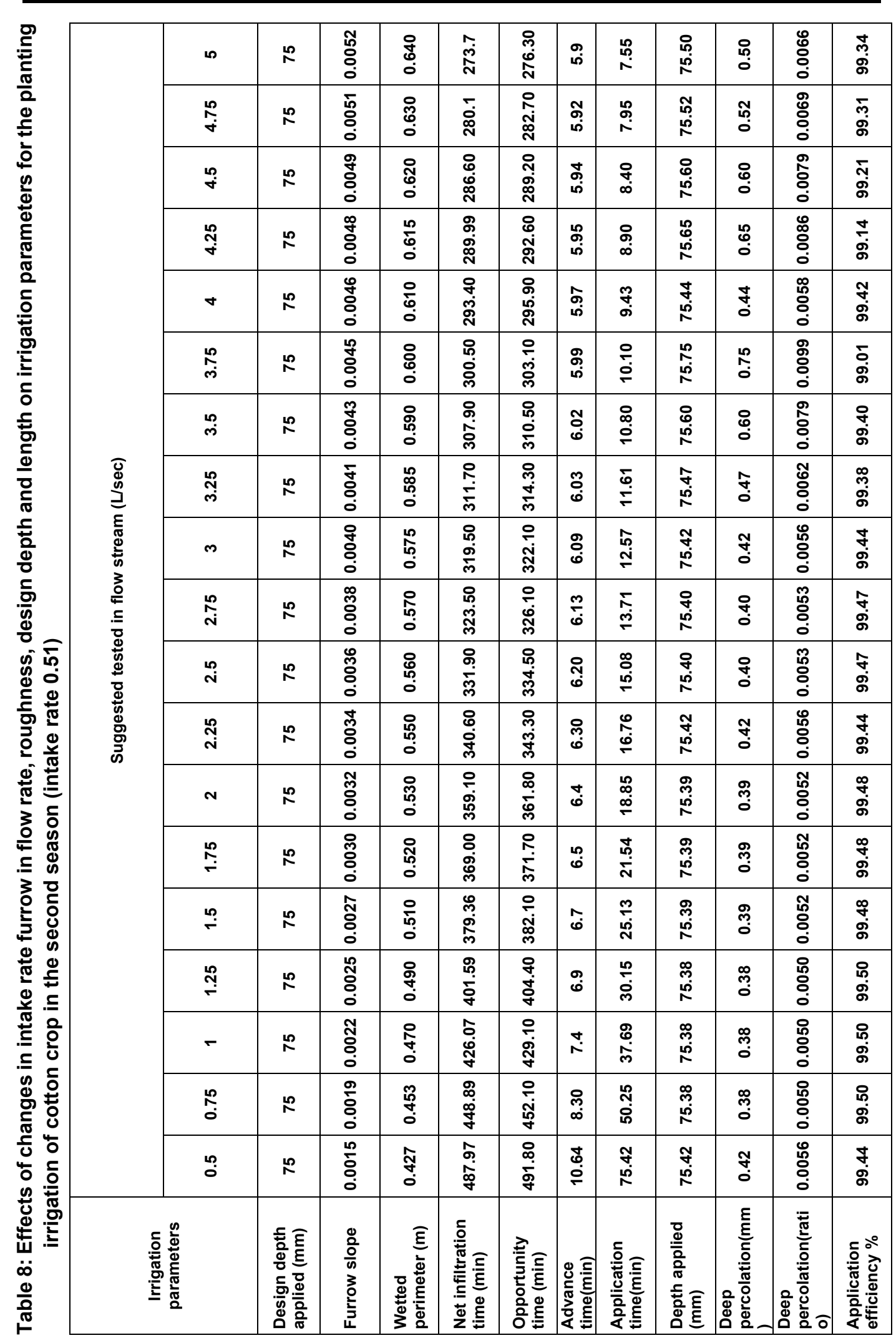


M.A. Aiad, et al.,

under traditional land leveling and irrigation discharge at $2 \mathrm{Lps} / \mathrm{m}$. While the lowest value of irrigation time was obtained under $0.1 \%$ ground surface slope combined with irrigation discharge of $3.3 \mathrm{Lps} \mathrm{Im}$

\subsection{Advance time:}

The design advance time for furrow length was lower than the actual measured one since the values were 6.4, 6.13 and 6.1 minutes for irrigation discharge at 2,0 2.7 and $3.3 \mathrm{Lps} / \mathrm{m}$ in the first and second seasons, respectively. On the other hand, the measured advance time was more than under traditional land leveling combined with irrigation discharge at $2.0 \mathrm{Lps} / \mathrm{m}$ in the first and second seasons respectively. The lowest values of measured advance time were obtained with $0.1 \%$ ground surface slope in combination with irrigation discharge of $3.3 \mathrm{Lps} / \mathrm{m}$.

\subsection{Recession time / opportunity} time and irrigation time I advance time:

It can be seen from Tables $9-12$ that the design values of recession, opportunity time and irrigation time I advance time were more than the measured values. The highest values of these parameters were recorded with interaction between the traditional land leveling and irrigation discharge at 2 Lps/m. While the lowest values were obtained under $0.1 \%$ ground surface slope combined with irrigation discharge at $3.3 \mathrm{Lps} / \mathrm{m}$.

\subsection{Advanced ratio, depth applied, deep percolation and deep percolation ratio:}

The highest values of advanced ratio, irrigation depth applied, deep percolation and deep percolation ratio were recorded with measured parameters compared to design parameters. Under field conditions, data indicated that the lowest values of the stated parameters were achieved with $0.1 \%$ ground surface slope combined with irrigation discharge at $\mathbf{3 . 3}$ $\mathrm{Lps} / \mathrm{m}$. It should be mentioned that the ratio of inflow time to advance time as well as for design parameters is more than 2 under irrigation discharge at $\mathbf{2 . 0}$ and $2.7 \mathrm{Lps} / \mathrm{m}$. While under field experiment, the ratio of inflow time to advanced time is more than 3 with irrigation discharge at $2 \mathrm{Lps} / \mathrm{m}$ under precision land leveling, $0.05 \%$ ground surface slope and $0.1 \%$ ground surface slope, meanwhile in this case the design is acceptable in clay soil and the design data agrees with measured data.

\subsection{Irrigation application efficiency:}

As the irrigation efficiencies depend on the volume of water infiltrated during the irrigation event and on the distribution of the infiltrated water across the field, so, the irrigation discharges, soil and water management are essential for prediction of efficiencies. Results showed that the highest designed value of application efficiency of $99.5 \%$ was obtained with inflow rate of $2 \mathrm{Lps} / \mathrm{m}$, meanwhile the lowest designed value of irrigation application efficiency was obtained with inflow rate of $3.3 \mathrm{Lps} / \mathrm{m}$. Under field conditions, the maximum measured values for irrigation application efficiency (IAE) were obtained from interaction between $0.1 \%$ ground surface slope and irrigation discharge at 2.7 Lps/ $\mathrm{m}$. While the lowest values of IAE were recorded from combination between traditional land leveling and irrigation discharge at $2 \mathrm{Lps} / \mathrm{m}$ in the first and second seasons. 
Soil Conservation Service (SCS) as a tool for proper design of cotton-furrow .......

Table 9: Comparison of measured and design conditions of furrow irrigation under traditional land leveling in planting irrigation of cotton crop in the first and second season

\begin{tabular}{|c|c|c|c|c|c|c|c|}
\hline \multirow{3}{*}{\multicolumn{2}{|c|}{ Irrigation parameters }} & \multicolumn{6}{|c|}{ Irrigation inflow rate (Lps/m) } \\
\hline & & \multicolumn{3}{|c|}{ first season } & \multicolumn{3}{|c|}{ second season } \\
\hline & & 2.0 & 2.7 & 3.3 & 2.0 & 2.7 & 3.3 \\
\hline \multicolumn{2}{|c|}{ furrow length(m) } & 40 & 40 & 40 & 40 & 40 & 40 \\
\hline \multicolumn{2}{|c|}{ furrow spacing (m) } & 0.75 & 0.75 & 0.75 & 0.75 & 0.75 & 0.75 \\
\hline \multirow{2}{*}{$\begin{array}{l}\text { furrow inflow } \\
\text { rate(Lps/m) }\end{array}$} & design & 2.00 & 2.00 & 2.00 & 2.00 & 2.00 & 2.00 \\
\hline & measured & 2.00 & 2.70 & 3.30 & 2.00 & 2.70 & 3.30 \\
\hline \multirow{2}{*}{$\begin{array}{l}\text { irrigation time } \\
\text { (min) }\end{array}$} & design & 18.85 & 13.70 & 11.61 & 18.85 & 13.70 & 11.61 \\
\hline & measured & 36 & 25 & 20 & 38 & 27 & 23 \\
\hline \multirow{2}{*}{$\begin{array}{l}\text { advance time } \\
\text { (min) }\end{array}$} & design & 6.4 & 6.13 & 6.1 & 6.4 & 6.13 & 6.1 \\
\hline & measured & 20.0 & 18.0 & 17.0 & 19.0 & 17.0 & 16.0 \\
\hline \multirow{2}{*}{$\begin{array}{l}\text { recession } \\
\text { time } \\
(\min )\end{array}$} & design & 338.82 & 306.03 & 295.04 & 368.2 & 332.23 & 320.4 \\
\hline & measured & 183.00 & 173.00 & 163.00 & 181.00 & 175.00 & 167.00 \\
\hline \multirow{2}{*}{$\begin{array}{l}\text { opportunity } \\
\text { time (min) }\end{array}$} & design & 332.42 & 299.90 & 289.00 & 361.80 & 326.10 & 314.30 \\
\hline & measured & 163.0 & 155.0 & 146.0 & 162.0 & 158.00 & 151.0 \\
\hline \multirow{2}{*}{$\begin{array}{l}\text { advance } \\
\text { ratio }\end{array}$} & design & 0.0193 & 0.0200 & 0.0210 & 0.0180 & 0.0190 & 0.0194 \\
\hline & measured & 0.1230 & 0.1160 & 0.1160 & 0.1173 & 0.10760 & 0.1059 \\
\hline \multirow{2}{*}{$\begin{array}{c}\text { irrigation } \\
\text { time/ } \\
\text { advance time }\end{array}$} & design & 2.95 & 2.23 & 1.90 & 2.95 & 2.23 & 1.90 \\
\hline & measured & 1.80 & 1.39 & 1.18 & 2.00 & 1.59 & 1.44 \\
\hline \multirow{2}{*}{$\begin{array}{c}\text { depth applied } \\
(\mathrm{mm})\end{array}$} & design & 75.4 & 75.46 & 75.47 & 75.39 & 75.40 & 75.47 \\
\hline & measured & 108 & 101.3 & 99.0 & 114.0 & 109.4 & 108.90 \\
\hline \multirow{2}{*}{$\begin{array}{c}\text { deep } \\
\text { percolation } \\
(\mathrm{mm})\end{array}$} & design & 0.4 & 0.46 & 0.47 & 0.39 & 0.40 & 0.47 \\
\hline & measured & 24.7 & 20.0 & 18.5 & 18.5 & 16.7 & 14.3 \\
\hline \multirow{2}{*}{$\begin{array}{c}\text { deep } \\
\text { percolation } \\
\text { ratio }\end{array}$} & design & 0.0053 & 0.0061 & 0.0062 & 0.0052 & 0.0053 & 0.0062 \\
\hline & measured & 0.2290 & 0.19700 & 0.1870 & 0.1623 & 0.1527 & 0.1313 \\
\hline \multirow{2}{*}{$\begin{array}{l}\text { application } \\
\text { efficiency\% }\end{array}$} & design & 99.47 & 99.39 & 99.38 & 99.48 & 99.47 & 99.38 \\
\hline & measured & 54.90 & 58.14 & 53.64 & 56.20 & 59.80 & 54.75 \\
\hline
\end{tabular}


M.A. Aiad, et al.,

Table 10: Comparison of measured and design conditions of furrow irrigation under precision land leveling in planting irrigation of cotton crop in the first and second season

\begin{tabular}{|c|c|c|c|c|c|c|c|}
\hline \multirow{3}{*}{\multicolumn{2}{|c|}{ Irrigation parameters }} & \multicolumn{6}{|c|}{ Irrigation inflow rate (Lps/m) } \\
\hline & & \multicolumn{3}{|c|}{ first season } & \multicolumn{3}{|c|}{ second season } \\
\hline & & 2.0 & 2.7 & 3.3 & 2.0 & 2.7 & 3.3 \\
\hline \multicolumn{2}{|c|}{ furrow length(m) } & 40 & 40 & 40 & 40 & 40 & 40 \\
\hline \multicolumn{2}{|c|}{ furrow spacing $(\mathrm{m})$} & 0.75 & 0.75 & 0.75 & 0.75 & 0.75 & 0.75 \\
\hline \multirow{2}{*}{$\begin{array}{c}\text { furrow } \\
\text { inflow } \\
\text { rate }(L p s / m)\end{array}$} & design & 2.00 & 2.00 & 2.00 & 2.00 & 2.00 & 2.00 \\
\hline & measured & 2.00 & 2.70 & 3.30 & 2.00 & 2.70 & 3.30 \\
\hline \multirow{2}{*}{$\begin{array}{l}\text { irrigation } \\
\text { time } \\
\text { (min) }\end{array}$} & design & 18.85 & 13.70 & 11.61 & 18.85 & 13.71 & 11.61 \\
\hline & measured & 34 & 23 & 18 & 35 & 25 & 20 \\
\hline \multirow{2}{*}{$\begin{array}{c}\text { advance } \\
\text { time } \\
\text { (min) }\end{array}$} & design & 6.4 & 6.13 & 6.1 & 6.4 & 6.13 & 6.1 \\
\hline & measured & 10.0 & 9.0 & 8.5 & 9.8 & 8.8 & 8.4 \\
\hline \multirow{2}{*}{$\begin{array}{l}\text { recession } \\
\text { time } \\
\text { (min) }\end{array}$} & design & 338.82 & 306.03 & 295.04 & 368.2 & 332.23 & 320.4 \\
\hline & measured & 124.00 & 109.00 & 98.00 & 115.00 & 104.00 & 96.00 \\
\hline \multirow{2}{*}{$\begin{array}{c}\text { opportunity } \\
\text { time (min) }\end{array}$} & design & 332.42 & 299.90 & 289.00 & 361.80 & 326.10 & 314.30 \\
\hline & measured & 114.0 & 100.0 & 89.5 & 105.2 & 95.20 & 87.6 \\
\hline \multirow{2}{*}{$\begin{array}{l}\text { advance } \\
\text { ratio }\end{array}$} & design & 0.0190 & 0.0200 & 0.0210 & 0.0180 & 0.0190 & 0.0190 \\
\hline & measured & 0.0877 & 0.0900 & 0.0949 & 0.0932 & 0.09200 & 0.0960 \\
\hline \multirow{2}{*}{$\begin{array}{l}\text { Irrigation } \\
\text { time/ } \\
\text { advance } \\
\text { time } \\
\end{array}$} & design & 2.95 & 2.23 & 1.90 & 2.95 & 2.23 & 1.90 \\
\hline & measured & 3.40 & 2.56 & 2.12 & 3.57 & 2.84 & 2.38 \\
\hline \multirow{2}{*}{$\begin{array}{l}\text { depth } \\
\text { applied } \\
\text { (mm) }\end{array}$} & design & 75.4 & 75.46 & 75.47 & 75.39 & 75.40 & 75.47 \\
\hline & measured & 102 & 93.0 & 89.0 & 105.2 & 101.3 & 99.0 \\
\hline \multirow{2}{*}{$\begin{array}{c}\text { deep } \\
\text { percolation } \\
(\mathrm{mm})\end{array}$} & design & 0.4 & 0.46 & 0.47 & 0.39 & 0.40 & 0.47 \\
\hline & measured & 22.7 & 19.0 & 16.0 & 16.9 & 14.8 & 13.5 \\
\hline \multirow{2}{*}{$\begin{array}{l}\text { deep } \\
\text { percolation } \\
\text { ratio }\end{array}$} & design & 0.0053 & 0.0061 & 0.0062 & 0.0052 & 0.0053 & 0.0062 \\
\hline & measured & 0.2230 & 0.20400 & 0.1790 & 0.1606 & 0.1461 & 0.1364 \\
\hline \multirow{2}{*}{$\begin{array}{l}\text { application } \\
\text { efficiency\% }\end{array}$} & design & 99.47 & 99.39 & 99.38 & 99.48 & 99.47 & 99.38 \\
\hline & measured & 62.34 & 67.82 & 64.50 & 57.30 & 60.40 & 56.10 \\
\hline
\end{tabular}


Soil Conservation Service (SCS) as a tool for proper design of cotton-furrow .......

Table 11: Comparison of measured and design conditions of furrow irrigation under $0.05 \%$ ground surface slope in planting irrigation of cotton crop in the first and second season

\begin{tabular}{|c|c|c|c|c|c|c|c|}
\hline \multirow{3}{*}{\multicolumn{2}{|c|}{ irrigation parameters }} & \multicolumn{6}{|c|}{ irrigation inflow rate (Lps/m) } \\
\hline & & \multicolumn{3}{|c|}{ first season } & \multicolumn{3}{|c|}{ second season } \\
\hline & & 2.0 & 2.7 & 3.3 & 2.0 & 2.7 & 3.3 \\
\hline \multicolumn{2}{|l|}{ furrow length(m) } & 40 & 40 & 40 & 40 & 40 & 40 \\
\hline \multicolumn{2}{|c|}{ furrow spacing $(\mathrm{m})$} & 0.75 & 0.75 & 0.75 & 0.75 & 0.75 & 0.75 \\
\hline \multirow{2}{*}{$\begin{array}{l}\text { furrow inflow } \\
\text { rate (Lps/m) }\end{array}$} & design & 2.00 & 2.00 & 2.00 & 2.00 & 2.00 & 2.00 \\
\hline & measured & 2.00 & 2.70 & 3.30 & 2.00 & 2.70 & 3.30 \\
\hline \multirow{2}{*}{$\begin{array}{l}\text { irrigation time } \\
\text { (min) }\end{array}$} & design & 18.85 & 13.70 & 11.61 & 18.85 & 13.71 & 11.61 \\
\hline & measured & 32 & 21 & 17 & 32 & 22 & 17 \\
\hline \multirow{2}{*}{$\begin{array}{l}\text { advance time } \\
\text { (min) }\end{array}$} & design & 6.4 & 6.13 & 6.1 & 6.4 & 6.13 & 6.1 \\
\hline & measured & 9.7 & 8.8 & 8.4 & 9.5 & 8.5 & 8.3 \\
\hline \multirow{2}{*}{$\begin{array}{l}\text { recession time } \\
\text { (min) }\end{array}$} & design & 338.8 & 306.03 & 295.04 & 368.2 & 332.23 & 320.4 \\
\hline & measured & 114.00 & 104.00 & 84.00 & 110.00 & 99.00 & 94.00 \\
\hline \multirow{2}{*}{$\begin{array}{l}\text { opportunity } \\
\text { time (min) }\end{array}$} & design & 332.42 & 299.90 & 289.00 & 361.80 & 326.10 & 314.30 \\
\hline & measured & 104.3 & 95.2 & 75.6 & 100.5 & 90.5 & 85.7 \\
\hline \multirow{2}{*}{$\begin{array}{c}\text { advance } \\
\text { ratio }\end{array}$} & design & 0.0190 & 0.0200 & 0.0210 & 0.0177 & 0.0188 & 0.0194 \\
\hline & measured & 0.0930 & 0.0920 & 0.1000 & 0.0945 & 0.09390 & 0.0968 \\
\hline \multirow{2}{*}{$\begin{array}{l}\text { irrigation time/ } \\
\text { advance time }\end{array}$} & design & 2.95 & 2.23 & 1.90 & 2.95 & 2.23 & 1.90 \\
\hline & measured & 3.30 & 2.39 & 2.02 & 3.37 & 2.59 & 2.05 \\
\hline \multirow{2}{*}{$\begin{array}{l}\text { depth applied } \\
(\mathrm{mm})\end{array}$} & design & 75.4 & 75.46 & 75.47 & 75.39 & 75.40 & 75.47 \\
\hline & measured & 96 & 85.1 & 84.2 & 96 & 89 & 84.2 \\
\hline \multirow{2}{*}{$\begin{array}{c}\text { deep } \\
\text { percolation } \\
(\mathrm{mm})\end{array}$} & design & 0.4 & 0.46 & 0.47 & 0.39 & 0.40 & 0.47 \\
\hline & measured & 20.6 & 17.0 & 15.5 & 15.7 & 13.9 & 12.2 \\
\hline \multirow{2}{*}{$\begin{array}{l}\text { deep } \\
\text { percolation } \\
\text { ratio }\end{array}$} & design & 0.0053 & 0.0061 & 0.0062 & 0.0052 & 0.0053 & 0.0062 \\
\hline & measured & 0.0109 & 0.00234 & 0.0028 & 0.1634 & 0.1562 & 0.1449 \\
\hline \multirow{2}{*}{$\begin{array}{l}\text { application } \\
\text { efficiency\% }\end{array}$} & design & 99.47 & 99.39 & 99.38 & 99.48 & 99.47 & 99.38 \\
\hline & measured & 65.40 & 73.20 & 68.30 & 64.20 & 71.80 & 69.60 \\
\hline
\end{tabular}


M.A. Aiad, et al.,

Table 12: Comparison of measured and design conditions of furrow irrigation under $0.1 \%$ ground surface slope in planting irrigation of cotton crop in the first and second season

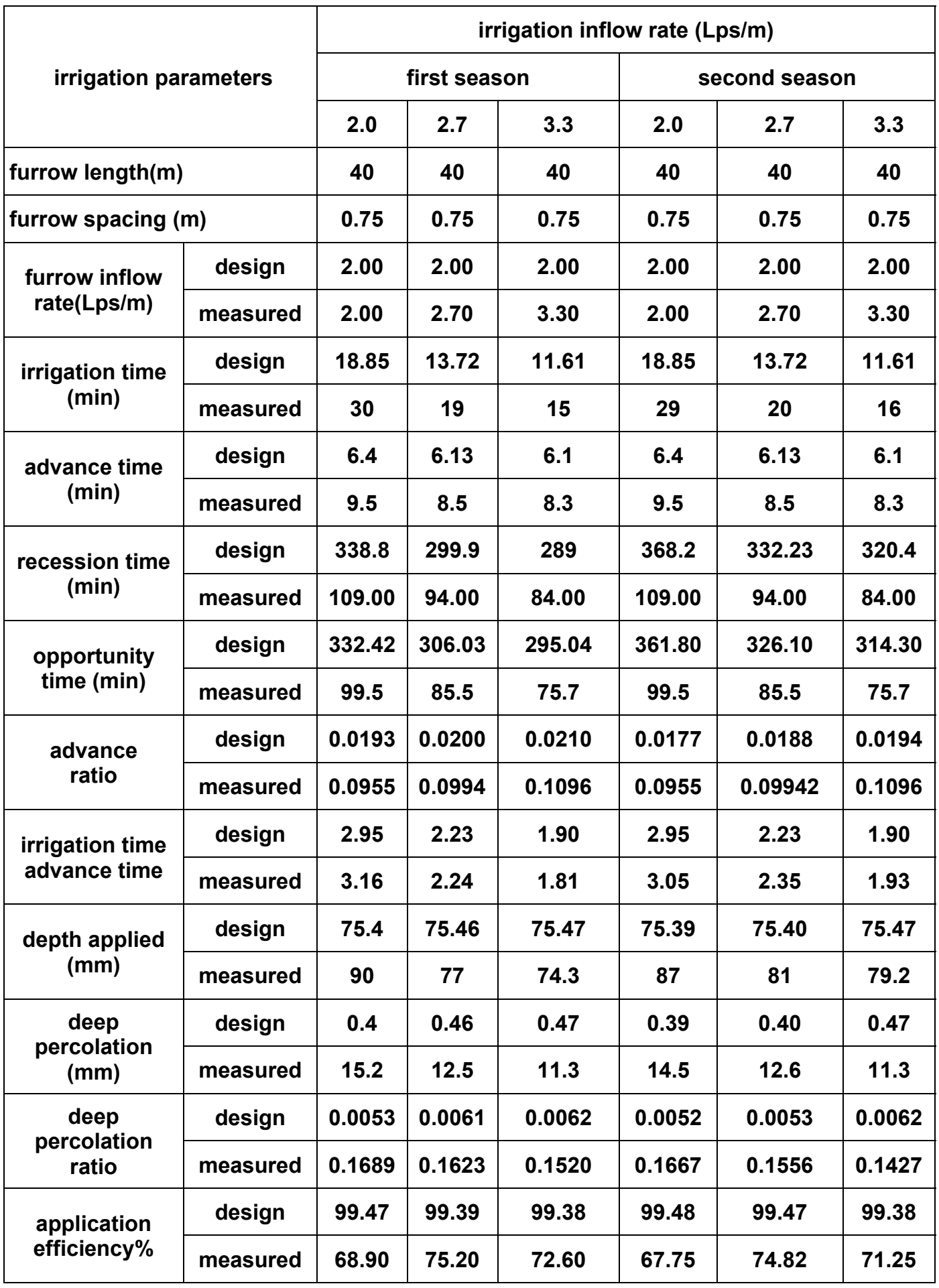


11. Economic evaluation:

Economic assessment requires special items through which the evaluation process can be executed. Tables (13 to 16) show the production cost values of the various involved components in the evaluation process. The suggested items of the economic evaluation for each treatment (separately) to trade-offs between them, economically are:

1- Seed cotton yield.

2- Total return.

3- Total cost.

4- Net return (NR) = total return - total cost.

5- Benefit - cost ratio $(B C R)=$ total return I total cost.

6- Specific cost, $($ LE $/ \mathrm{kg})=$ total cost $/$ seed cotton yield

Table 13: Agricultural operations costs and labour wages for cotton production in 2017 and 2018 seasons

\begin{tabular}{|c|c|c|}
\hline \multicolumn{2}{|r|}{ Item } & Cost according to the \\
\hline \multirow{3}{*}{$\begin{array}{l}\text { Chemical } \\
\text { fertilizer }\end{array}$} & $\begin{array}{l}\mathrm{N} \text {, as urea, } 46.5 \%(90 \mathrm{~N} \text { unit } / \mathrm{fed}) \text { was } \\
\text { applied=193.5kg/fed }\end{array}$ & 4000 LE/ton \\
\hline & $\begin{array}{l}\mathrm{K} \text {, as potassium sulphate, } 48 \%(50 \mathrm{~kg} / \mathrm{fed} \text {.as } \\
\text { are commended rate in clay soil }\end{array}$ & 8000 LE/ton \\
\hline & $\begin{array}{l}\mathrm{P} \text {, as calcium superphosphate, } 15.5 \% \mathrm{P}_{2} \mathrm{O}_{5} \\
(200 \mathrm{~kg} / \mathrm{fed} \text {.as a recommended rate in clay soil } \\
\text { added during the last plowing before planting }\end{array}$ & 1400 LE/ton \\
\hline \multirow{2}{*}{ Seeds } & \multirow{2}{*}{$30 \mathrm{Kg}$ seeds } & 10 LE/kg \\
\hline & & 300LE /fed \\
\hline \multirow{5}{*}{$\begin{array}{l}\text { Machinery } \\
\text { costs }\end{array}$} & Plowing & 300 LE/fed \\
\hline & Scraping & 150 LE/fed \\
\hline & Precision lazer land leveling & 285 LE/fed \\
\hline & Furrowing & 150 LE/fed \\
\hline & Irrigation & 300LE /fed \\
\hline \multirow{6}{*}{$\begin{array}{l}\text { Lab our } \\
\text { wages }\end{array}$} & Planting & 400 LE/fed \\
\hline & Hoeing & 500 LE/fed \\
\hline & Fertilizer broadcast & 200 LE/fed \\
\hline & Irrigation & 200LE/fed \\
\hline & Harvesting & 4000LE /fed \\
\hline & Manual weed control & 200LE/fed \\
\hline \multicolumn{2}{|l|}{ Pesticide } & 1000 LE/fed \\
\hline \multicolumn{2}{|c|}{ Land rent for summer season } & 5000LE/fed \\
\hline \multicolumn{2}{|c|}{ Gated pipes installation } & 840LE /fed \\
\hline \multicolumn{2}{|c|}{ Seed cotton yield (LE/fed) } & 2400LE/fed \\
\hline
\end{tabular}


M.A. Aiad, et al.,

Table 14: Values of production cost components per Fadden for different treatments (LE Fed $^{-1}$ ) during the two growing seasons

\begin{tabular}{|c|c|c|c|c|c|c|c|c|c|c|c|c|}
\hline \multirow{3}{*}{$\begin{array}{r}\text { Cost } \\
\text { items }\end{array}$} & \multicolumn{12}{|c|}{ Cost values for various agronomic operations LE } \\
\hline & \multicolumn{3}{|c|}{$\begin{array}{l}\text { traditional } \\
\text { irrigation }\end{array}$} & \multicolumn{3}{|c|}{ Dead level } & \multicolumn{3}{|c|}{$0.05 \%$ slope } & \multicolumn{3}{|c|}{$0.1 \%$ slope } \\
\hline & 2.0 & 2.7 & 3.3 & 2.0 & 2.7 & 3.3 & 2.0 & 2.7 & 3.3 & 2.0 & 2.7 & 3.3 \\
\hline $\mathbf{N}$, Urea & 774 & 774 & 774 & 774 & 774 & 774 & 774 & 774 & 774 & 774 & 774 & 774 \\
\hline $\mathrm{K}, \mathrm{K}_{2} \mathrm{O}$ & 400 & 400 & 400 & 400 & 400 & 400 & 400 & 400 & 400 & 400 & 400 & 400 \\
\hline $\mathbf{P}, \mathrm{P}_{2} \mathrm{O}_{5}$ & 280 & 280 & 280 & 280 & 280 & 280 & 280 & 280 & 280 & 280 & 280 & 280 \\
\hline Seeds & 300 & 300 & 300 & 300 & 300 & 300 & 300 & 300 & 300 & 300 & 300 & 300 \\
\hline \begin{tabular}{|c|} 
Land \\
rent for \\
summer \\
\end{tabular} & 6000 & 6000 & 6000 & 6000 & 6000 & 6000 & 6000 & 6000 & 6000 & 6000 & 6000 & 6000 \\
\hline \multicolumn{13}{|c|}{ Mach cost, LE } \\
\hline Plowing & 300 & 300 & 300 & 300 & 300 & 300 & 300 & 300 & 300 & 300 & 300 & 300 \\
\hline Scraping & 150 & 150 & 150 & 0 & 0 & 0 & 0 & 0 & 0 & 0 & 0 & 0 \\
\hline \begin{tabular}{|c|}
$\begin{array}{c}\text { Lazer } \\
\text { leveling }\end{array}$ \\
\end{tabular} & 0.0 & 0.0 & 0.0 & 285 & 285 & 285 & 330 & 330 & 330 & 375 & 375 & 375 \\
\hline Furrowing & 150 & 150 & 150 & 150 & 150 & 150 & 150 & 150 & 150 & 150 & 150 & 150 \\
\hline Irrigation & 300 & 300 & 300 & 300 & 300 & 300 & 300 & 300 & 300 & 300 & 300 & 300 \\
\hline $\begin{array}{l}\text { Gated } \\
\text { pipes } \\
\text { labor }\end{array}$ & 840 & 840 & 840 & 840 & 840 & 840 & 840 & 840 & 840 & 840 & 840 & 840 \\
\hline \multicolumn{13}{|c|}{ Wages, LE } \\
\hline Planting & 400 & 400 & 400 & 400 & 400 & 400 & 400 & 400 & 400 & 400 & 400 & 400 \\
\hline Hoeing & 500 & 500 & 500 & 500 & 500 & 500 & 500 & 500 & 500 & 500 & 500 & 500 \\
\hline $\begin{array}{c}\text { Fertilizer } \\
\text { broadcast }\end{array}$ & 200 & 200 & 200 & 200 & 200 & 200 & 200 & 200 & 200 & 200 & 200 & 200 \\
\hline Irrigation & 200 & 200 & 200 & 200 & 200 & 200 & 200 & 200 & 200 & 200 & 200 & 200 \\
\hline Harvesting & 4000 & 4000 & 4000 & 4000 & 4000 & 4000 & 4000 & 4000 & 4000 & 4000 & 4000 & 4000 \\
\hline Pesticides & 1000 & 1000 & 1000 & 1000 & 1000 & 1000 & 1000 & 1000 & 1000 & 1000 & 1000 & 1000 \\
\hline \begin{tabular}{|c|} 
Manual \\
weed \\
control \\
\end{tabular} & 200 & 200 & 200 & 200 & 200 & 200 & 200 & 200 & 200 & 200 & 200 & 200 \\
\hline Total & 15794 & 15794 & 15794 & 16129 & 16129 & 16129 & 16174 & 16174 & 16174 & 15219 & 15219 & 15219 \\
\hline
\end{tabular}


Soil Conservation Service (SCS) as a tool for proper design of cotton-furrow .......

Table 15: Values of some features used for selection the profitable treatments for cotton crop (average the two seasons)

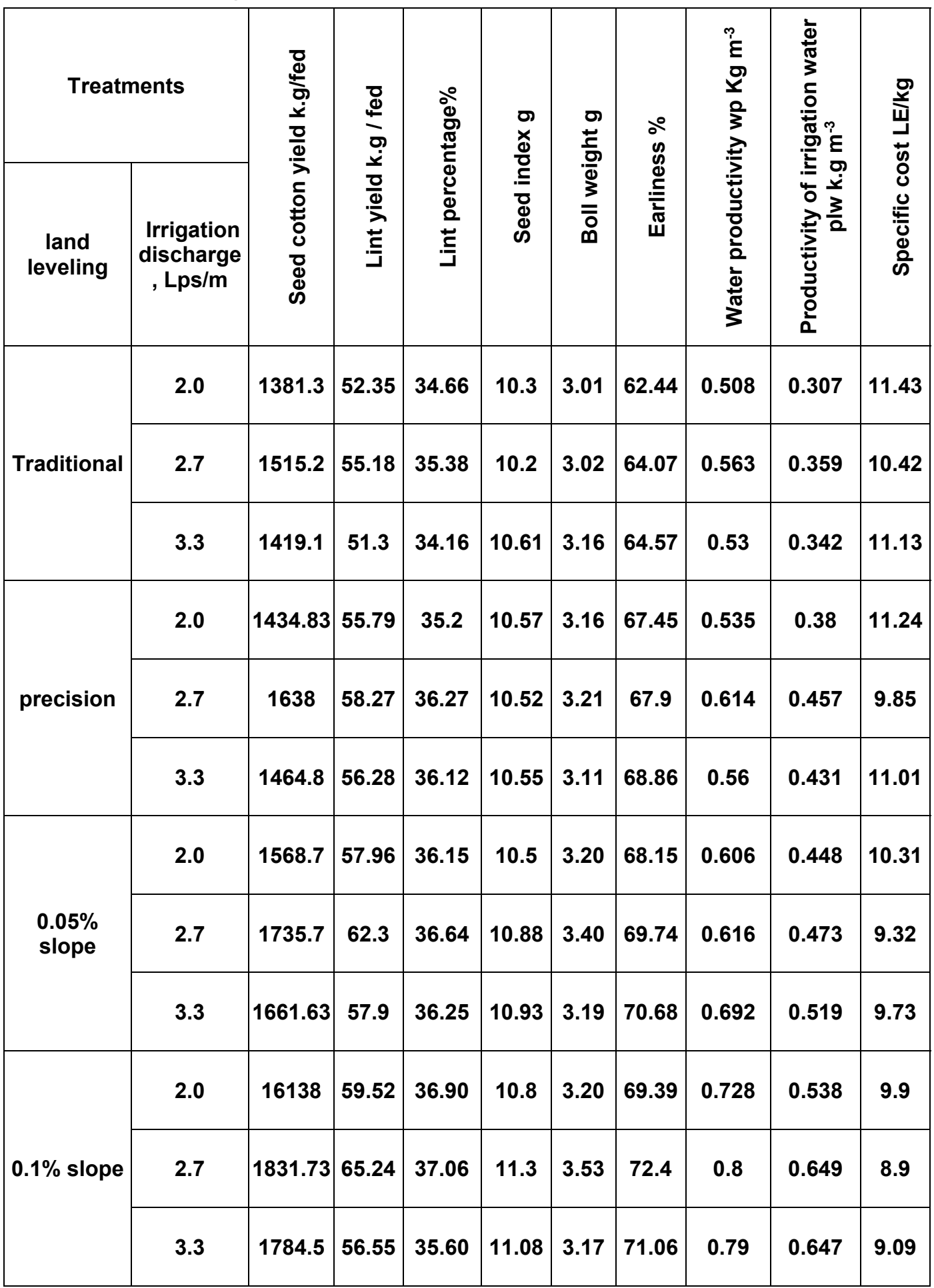


M.A. Aiad, et al.,

Table 16: Total return, Total cost, net return and some economic criteria for cotton production ( average of 2017 and 2018 seasons )

\begin{tabular}{|c|c|c|c|c|c|c|c|c|}
\hline Treat & nents & $\begin{array}{r}\text { Seed co } \\
\text { kantar }\end{array}$ & $\begin{array}{l}\text { on yield } \\
\text { d(k.g) }\end{array}$ & $\begin{array}{c}\text { Total } \\
\text { seasonal }\end{array}$ & $\begin{array}{c}\text { Total } \\
\text { seasonal }\end{array}$ & $\begin{array}{l}\text { Net } \\
\text { return }\end{array}$ & Benefit & Specific \\
\hline $\begin{array}{l}\text { Land } \\
\text { leveling }\end{array}$ & $\begin{array}{r}\text { Irrigation } \\
\text { discharge }\end{array}$ & $\begin{array}{l}\text { Kentar } \\
\text { (a) }\end{array}$ & $\begin{array}{l}\text { Fed } \\
\text { (k.g) }\end{array}$ & $\begin{array}{c}\text { LE/fed } \\
\text { (b) }\end{array}$ & $\begin{array}{l}\text { LE/fed } \\
\text { (c) }\end{array}$ & $\begin{array}{c}\text { fed (b- } \\
\text { c) }\end{array}$ & $\begin{array}{l}\text { ratio } \\
(\mathbf{b} / \mathbf{c})\end{array}$ & $\begin{array}{l}\text { LE/k.g } \\
\text { (c/a) }\end{array}$ \\
\hline & 2.0 & 8.77 & 1381.3 & 21048 & 15794 & 5254 & 1.33 & 11.43 \\
\hline & 2.7 & 9.62 & 1515.2 & 23088 & 15794 & 7294 & 1.46 & 10.42 \\
\hline & 3.3 & 9.01 & 1419.1 & 21624 & 15794 & 5830 & 1.37 & 11.13 \\
\hline & Mean & 9.13 & 1438.5 & 21920 & 15794 & & & \\
\hline & 2.0 & 9.11 & 1434.83 & 21864 & 16129 & 5735 & 1.36 & 11.24 \\
\hline Precision & 2.7 & 10.4 & 1638 & 24960 & 16129 & 8831 & 1.55 & 9.85 \\
\hline leveling & 3.3 & 9.3 & 1464.8 & 22320 & 16129 & 6191 & 1.38 & 11.01 \\
\hline & Mean & & & 23048 & 16129 & & & \\
\hline & 2.0 & 9.96 & 1568.7 & 23904 & 16174 & 7730 & 1.48 & 10.31 \\
\hline $\begin{array}{c}0.05 \% \\
\text { ground }\end{array}$ & 2.7 & 11.02 & 1735.7 & 26448 & 16174 & 10274 & 1.64 & 9.32 \\
\hline $\begin{array}{l}\text { surface } \\
\text { slope }\end{array}$ & 3.3 & 10.55 & 1661.63 & 25320 & 16174 & 9146 & 1.57 & 9.73 \\
\hline & Mean & & & 25224 & 16174 & & & \\
\hline & 2.0 & 10.4 & 1638 & 24960 & 16219 & 8741 & 1.53 & 9.9 \\
\hline $\begin{array}{c}0.1 \% \\
\text { ground }\end{array}$ & 2.7 & 11.63 & 1831.73 & 27912 & 16219 & 11693 & 1.7 & 8.9 \\
\hline $\begin{array}{c}\text { surface } \\
\text { slope }\end{array}$ & 3.3 & 11.33 & 1784.5 & 27192 & 16219 & 10973 & 1.68 & 9.09 \\
\hline & Mean & & & 26688 & 16219 & & & \\
\hline
\end{tabular}

I Kentar = 157.5K.G Seed Cotton

\subsection{Seed cotton yield}

Table 16 show the effect of different land leveling and irrigation discharge treatments on seed cotton yield as well the economic evaluation parameters as mean of the two studied seasons 2017 and 2018. Obtained data cleared out that the combination between land leveling of $0.1 \%$ ground surface and $2.71 \mathrm{ps} / \mathrm{m}$ as irrigation discharge achieved the highest value of seed cotton yield followed by irrigation discharge of $3.3 \mathrm{Lps} / \mathrm{m}$. While the lowest value of seed cotton yield was resulted from interaction between traditional land leveling and irrigation discharge of 2 IPS/M.

\subsection{Total Seasonal Return:}

From data tabulated in Table 16, the mean values of the total seasonal return were 21920, 23048, 25224 and 26688 LE I fed. for traditional land leveling, precision land leveling (dead level), $0.05 \%$ ground surface slope and $0.1 \%$ ground surface 
slope, respectively. Concerning the irrigation discharge, data show that the irrigation discharge at $2.7 \mathrm{Lps} / \mathrm{m}$ resulted in increased total seasonal return compared to other irrigation discharges. This trend may be attributed to increasing the seed cotton yield and growth parameters. It should be carefully mentioned that the total seasonal return increased by $5.15 \%, 15.07 \%$ and $21.75 \%$ under precision land leveling, $0.05 \%$ slope and $0.1 \%$ slope compared to the traditional land leveling. While, the increase in total seasonal return under irrigation discharge at 2.7 and $3.3 \mathrm{Lps} / \mathrm{m}$ were 11.54 and $2.1 \%$ compared to irrigation discharge at $2.0 \mathrm{Lps} / \mathrm{m}$.

\subsection{Net seasonal return:}

Data of Table 16 revealed that the net seasonal return showed the same trend as for the abovementioned indicator, (i.e. the seasonal total return). This trend may be due to that the production cost for each treatment, seemed to be the same, or that the differences between them are relatively small compared to the corresponding values of the differences between the return value for each treatment, which are relatively high. The highest value 11693 LE / fed was (27829 LE/ha, $1 \$=17.8$ LE, $1 \mathrm{fed}=0.42 \mathrm{ha}$ ) obtained with interaction between $0.1 \%$ ground surface slope and irrigation discharge at $2.7 \mathrm{Lps} / \mathrm{m}$. While the lowest value 5254 LE / fed (12505 LE/ha) was noticed under traditional land leveling and irrigation discharge at $2.0 \mathrm{Lps} / \mathrm{m}$.

\subsection{Benefit-cost ratio (BCR):}

From the presented data of Table 16, the interaction between $0.1 \%$ ground surface slope and irrigation discharge at 2.7 Lps/m achieved the highest value of BCR. While the traditional land leveling combined with irrigation discharge at 2.0 $\mathrm{Lps} / \mathrm{m}$ recorded the lowest value of benefit cost ratio. This may be attributed to the relatively same cost between and within treatments on one hand, comparing with considerable differences in return between those treatments.

\subsection{Specific cost (LE/kg):}

Specific cost decreased with land leveling at $0.1 \%$ ground surface slope and irrigation discharge at $2.7 \mathrm{Lps} / \mathrm{m}$. The lowest recorded value $8.85 \mathrm{LE} / \mathrm{Kg}$ was by applying $0.1 \%$ ground surface slope and irrigation discharge at $2.7 \mathrm{Lps} / \mathrm{m}$. Whereas the highest value $11.43 \mathrm{LE} / \mathrm{Kg}$ was obtained by applying the traditional land leveling and irrigation discharge at $2.0 \mathrm{Lps} / \mathrm{m}$. (Table 16). This finding is due to the lowest seed cotton yield.

\subsection{Selecting the most profitable treatment for cotton crop production:}

Nine parameters were taken into account to select the profitable treatment for cotton crop production under Egyptian conditions. These related parameters are: seed cotton yield, lint yield, lint percentage, seed index, boll weight, earliness, water productivity, productivity of irrigation water and specific cost as shown in Table 17.

It is suggested to use a factor called (overall relative factor of evaluation, kt). This factor is expressed as follows:

$K t=R 1 K 1$ * $R 2 K 2$ * R3K3 * R4K4 * R5K5 * $R 6 K 6$ * $R 7 K 7$ * $R 8 K 8$ * $R 9 K 9$

Where:

$\mathrm{K} 1=$ Seed cotton yield $/$ the same criterion for $0.1 \%$ ground surface slope and irrigation discharge at $2.7 \mathrm{Lps} / \mathrm{m}$

K2 = Lint Yield for the tested treatment $I$ the same criterion for $0.1 \%$ slope and 2.7 Lps/m

$\mathrm{K} 3$ = Lint percentage for the tested treatment / the same criterion for $0.1 \%$ slope and $2.7 \mathrm{Lps} / \mathrm{m}$ K4 = Seed index for the tested treatment $I$ the same criterion for $0.1 \%$ slope and 2.7 Lps/m 


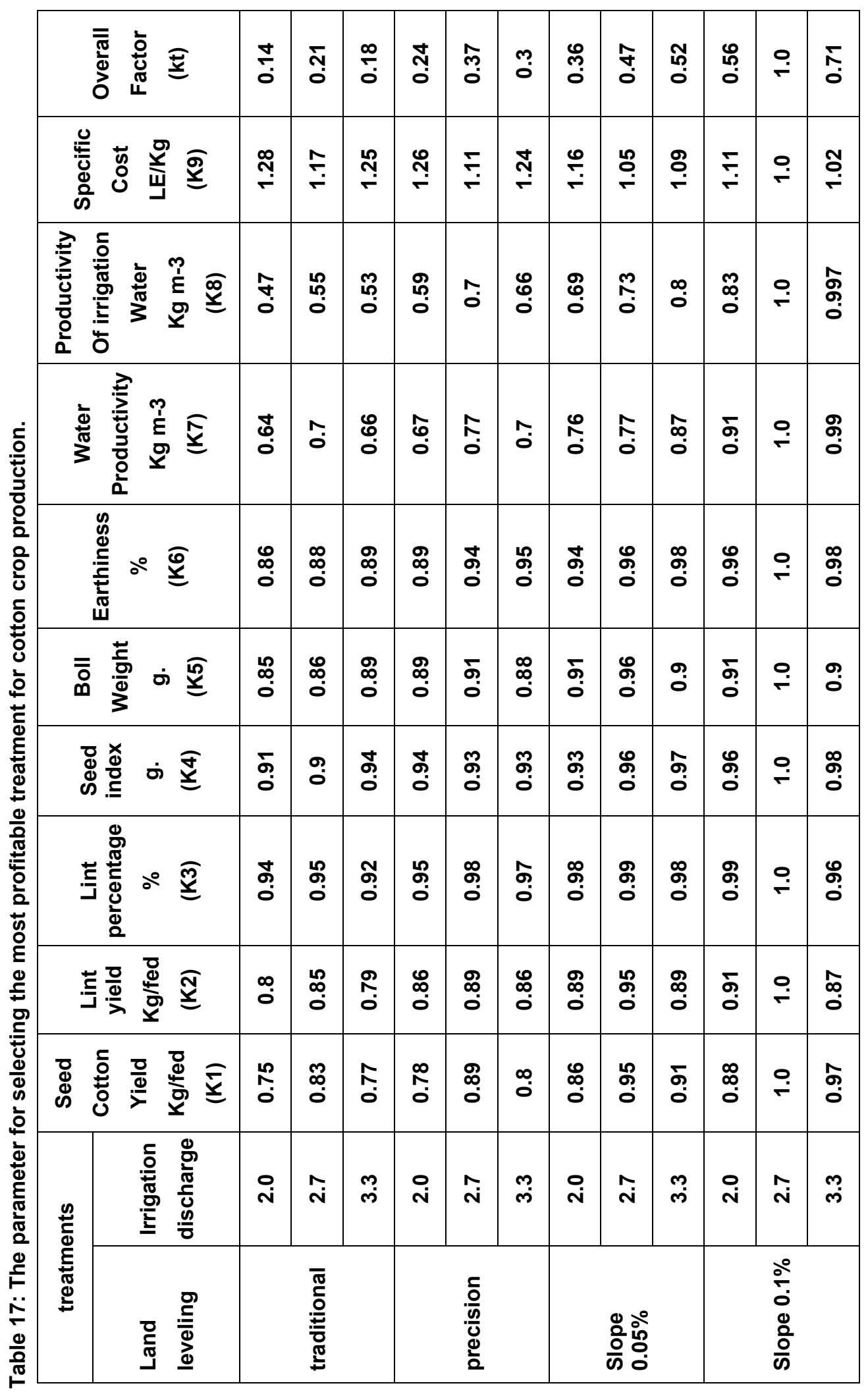


K5 = Boll weight for the tested treatment I the same criterion for $0.1 \%$ slope and 2.7 Lps/m

K6 $=$ Earliness percentage for the tested treatment $/$ the same criterion for $0.1 \%$ slope and $2.7 \mathrm{Lps} / \mathrm{m}$

K7 = Water productivity for the tested treatment $/$ the same criterion for $0.1 \%$ slope and $2.7 \mathrm{Lps} / \mathrm{m}$

K8 = Productivity of irrigation water for the tested treatment / the same criterion for $0.1 \%$ slope and $2.7 \mathrm{Lps} / \mathrm{m}$

$\mathrm{K} 9$ = Specific cost for the tested treatment $/$ the same criterion for $0.1 \%$ slope and $2.7 \mathrm{Lps} / \mathrm{m}$.

The combined of these parameters may help to set up an overall relative factor of evaluation for each treatment and selecting an optimum treatment that meet the best results of all or most evaluation features. The importance of each parameter differs according to marketing and environmental conditions, so the values of $\mathrm{Ri}, \mathrm{i}=1-9$ were taken throughout this work to be equal the unity. Therefore, this action or procedure simplifies the abovementioned formula to be as follows:

$\mathrm{Kt}=\mathrm{K} 1^{*} \mathrm{~K}{ }^{*} \mathrm{~K} 3^{*} \mathrm{~K} 4{ }^{*} \mathrm{~K} 5^{*} \mathrm{~K} 6{ }^{*} \mathrm{~K} 7^{*} \mathrm{~K} 8^{*} \mathrm{~K}$.

It should be noted herewith that $0.1 \%$ ground surface slope and irrigation discharge 2.7 Lps/m which was used in this research as a basis to calculate the value of overall relative factor of evaluation (kt) for all treatments. So, the values of $\mathrm{k} 1$ to $\mathrm{k} 9$ for the treatment $0.1 \%$ slope and $2.7 \mathrm{Lps} / \mathrm{M}$ should be equal to the unity, and consequently, the value of kt for the base treatment must also be equal to unity. Table 17 which show the values of $k 1$ through $k 9$ for the different investigated treatments and the corresponding values of overall factors of evaluation. It is clear that the value of overall factor (kt) of evaluation differs according to the investigated treatments.
So, the different tested treatments of cotton production can be arranged in the following descending order:

$0.1 \%$ slope and $2.7 \mathrm{Lps} / \mathrm{m}>0.1 \%$ slope and $3.3 \mathrm{Lps} / \mathrm{m}>0.1 \%$ slope and 2 Lps/m > $0.05 \%$ slope $\times 3.3 \mathrm{Lps} / \mathrm{m}>0.05$ $\%$ slope $\times 2.71 \mathrm{ps} / \mathrm{m}>$ precision land leveling x $2.7 \mathrm{Lps} / \mathrm{m}>0.05 \%$ slope $\times 2$ $\mathrm{Lps} / \mathrm{m}>$ precision land leveling $\times 3.3$ $\mathrm{Lps} / \mathrm{m}>$ precision land leveling $\times 2.0$ Lps $/ \mathrm{m}>$ traditional land leveling $\times 3.3$ Lps $/ \mathrm{m}>$ traditional land leveling $\times 2.0$ Lps/m.

Therefore, it can be carefully recommended that the land leveling 0.1 $\%$ ground surface slope combined with 2.7 Lps/m is the best or the highest treatment which meet the best desired results.

\section{Conclusion}

and recommendations.

Soil conservation service (SCS) with its parameters could be fairly used in design furrow surface irrigation for the clayey soils of North Nile Delta. Consequently, -Inflow rate of $2 \mathrm{Lps} / \mathrm{m}$ executed under processing land leveling of 0.05 or $0.1 \%$ could be acceptable due to

*high application efficiency of irrigation water,

*for inflow rate less than $21 \mathrm{ps} / \mathrm{m}$, irrigation time is excessive,

*lowest deep percolation and deep percolation ratio were achieved and, increasing net infiltration time, advance time and opportunity time in response of increasing inflow rate.

Therefore, further studies, analysis and evaluation regarding the usage of SCS in design furrow irrigation system in the clayey soils of North Nile Delta is urgently needed. 


\section{REFERENCES}

Abd El-Rasool, S.F., H.W. Tawadros, W.I. Miseha and F.N. Mahrous (1971). Effect of irrigation and fertilization on water use efficiency by wheat. Fertilization Conf. Ain Shams Univ., Cairo, Egypt

Abdel Reheem, H. A. (2017). Optimizing water use efficiency for sugar can crop. New York Science Journal, 10: 97-108.

Abo Soliman, M. S. M., H. A. Shams ElDin, M. M. Saied, S. M. El-Barbary, M. A. Ghazy and M. I. El-Shahawy (2008). Impact of field irrigation management on some irrigation efficiencies and production of wheat and soybean crops. Zagazig. J. Agric. Res., 35: 363 -381 .

Amer, A. M. (2011). Evaluation of surface irrigation as a function of water infiltration in cultivated soils in the Nile Delta. Irrig. Drainage System, 25: 367-383.

Asseng, S., A. M. S. Kheir, B. T. Kassie, G. Hoogenboom, A. I. N. Abdelaal, D. Z. Haman and A. C. Ruane (2018). Can Egypt become self-sufficient in wheat? Environmental Research Letters, 13: 094012.

Atiea, A. M. (1986). Economics of Farm Mechanization. The Egyptian Public Authority for Book.

Brater, E. F. and H. W. King (1976). Handbook of hydraulics. Mcgeavy, Hill Book Company, 61.

Campbell, D. J. (1994). Determination and use of bulk density in relation to soil compaction. In Soane and Ouwerk (Ed.).Soil Compaction in Crop Production, Elsevier, London and Amsterdam.

Downy, L. A. (1970). Water use by maize at three plant densities. Exper., Agric, 7: 161-169.

El-Beltagy, A. T. and A. F. Abo-Hadeed (2008). The main pillars of the National
Program for maximizing the water use efficiency in the old land The Research and Development council. Ministry of Agriculture and Land Reclamation (MALR) Giza, Egypt (in Arabic).

El-Hadidi, E. M., M. M. Saied, Fatma M. and R. M. Khalifa (2016). Assessing the effect of water discharge rates and cut-off irrigation on wheat production and some water relations at North Nile Delta Region. J. Soil Sci. and Agric. Eng., Mansoura Univ., 7: 397-407.

El-Hendawy, S. E., E. A. Abd El-Lattief, M. S. Ahmed and U. Schmidhalter (2008). Irrigation Rate and Plant Density Effects on Yield and Water Use Efficiency of Drip-Irrigated Corn. Agricultural Water Management, 95: 836-844. http://dx.doi.org/10.1016/j.agwat.2008. 02.008 .

El-Mowelhi, N.M., M.S.M. Abo Soliman, H.A. Shams El-Din, J. Ayars and S.A. Hasanein (1995). On farm water management in soils of Kafr ElSheikh. II. Evaluation of land leveling practices and stream size under furrow irrigation system. Soil and Water Res., Int., Agric. Res. Center Conf., on Farm Irrigation and Agroclimatology, 2-4 January, 1995, Dokki Egypt, 157-164.

El-Shahawy, M.I. (2004). Some aspects of water management in furrow irrigation under cotton crop. J. Agric. Sci. Mansoura Univ., 29(6): 3651- 3660.

El-Quosy, D. (1998). The challenge for water in the twenty first century. The Egyptian Experience, Arab. Water. 98Ministry of water resources and irrigation (MWRI) April 26-28, Cairo, Egypt.

Eldeiry, A., L. Garcia, A. S. A. El-Zaher and M. El-Sherbini Kiwan (2005). Furrow irrigation system design for clay soils in Arid Regions. Appl. Eng. Agric, 21: 411-420. 
Ewup. (1983). Egypt Water Use Project Technical Report No.35 (1983)

Garcia, I. (1978). Soil Water Engineering Laboratory Manual. Agric. and Chem. Eng. Dept., Colorado State Univ., fort. Collins, USA.

Gillies, M. H. and R. J. Smith (2005). Infiltration parameters from surface irrigation advance and run-off data. Irrig. Sci., 24: 25-35.

Gillies, M. H., R. J. Smith and S. R. Raine (2008). Measurement and Management of furrow irrigation at the field scale. Irrigation Australia 2008 - share the water, share the Benefits: Irrigation Australia National Conference and Exhibition, Melbourne, Australia. http://eprints.usq.edu.au/4160/.

Hassan, A. Abdel-Raheem and A. M. Elwan (2016). Gated Pipes Irrigation System for Optimum Water Productivity of Sugar cane in Egypt. Journal of American Science; 12(7): 215- 225.

Holzapfel, E. A., C. Leiva, M. A. Mariño, J. Paredes, J. L. Arumí and M. Billib (2010). Furrow irrigation management and design criteria using efficiency parameters and simulation models. Chilean journal of agricultural research 70: 287-296.

Israelson, O.W. and V.E. Hansen (1962). "Irrigation Principles and Practices". 3 rd Ed.. John Willey \& Sons. New York.

Jackson, M.L. (1967). Soil Chemical Analysis. Prentice-Hall of India, New Delhi

James, L. G. (1988). Principles of farm irrigation system design. Johm willey \&Sons(ed.), New Yourk, pp,543.

Khalifa, R. M., M. M. Saied and M. R. Khalifa (2018). Improvement and Evaluation of Slide Irrigation Design in the Northern Delta Clay Soils. Egypt. J. Soil Sci. , 58: $207-220$.

Klute, A. (1986). Methods of Soil Analysis. Part1. Physical and
Mineralogical Methods. 2nd (Ed.). Amer. Soc. of Agron. Inc, Madison, Wisconsin, USA.

Michael, A.M. (1978). Irrigation Theory and Practice. Vikas Publishing House, New Delhi, 1978.

Osman, H. E. (2000). Gated pipes techniques for improved surface irrigation. 8th, Conf. As. Dev. Res., Ain Shams University, Cairo, November 20 - 22: $145-155$

Page, A. L., R. H. Miller and D. R. Keeney (1982). Methods of Soil Analysis. Part 2. Chemical and Microbiological properties. 2nd (Ed.). Amer. Soc. of Agron. Inc, Madison, Wisconsin, U.S.A. .

Pereira, L. S., T. Oweis and A. Zairi (2002). Irrigation management under water scarcity. Agric. Water Manage, 57: 175-206.

Pereira, L. S. and T. J. Trout (1999). Irrigation Methods. CIGR hand-book of agriculture engineering. land and water engineering, Vol. 1. H. N. Van lier, L.S. Pereira, and F.R Steiner, eds., ASAE, St. Joseph, Mich, 297-379.

Richards, L. A. (1954). "Diagnosis and Improving of Saline and Alkaline Soils". U. S., Salinity Laboratory Staff. Agric. Handbook, No.60.

Salahou, M. K., X. Jiao and L. Haishen (2018). Border irrigation performance with distance-based cut-off. Agric. Water Manag, 201: 27-37.

USDA. (1974). Border irrigation. National Engineering Handbook. Chapter 4, Section 15, SCS, U.S. Government printing office, Washington, D.C.

USDA. (1979). Furrow Irrigation. National Engineering Handbook. chapter5, section 15, SCS, U. S. Government Printing Office, Washington D.C.

Walker, W. R. (2005). "Multi-Level Calibration of Furrow Infiltration and Roughness." Journal of Irrigation and Drainage Engineering 131(2): 129-135. 
خدمه صيانه الاراضي (SCS) كأداة فعالة في التصميم المناسب لري القطن بالخطوط في الاراضي الطينية

محمود (بو الفتوح عياد(')، محمود محمد عبد الحي شبانة(')، ابراهيم محمد عبد الفتاح|(')

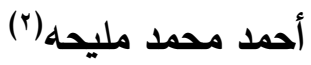

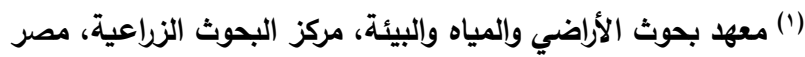

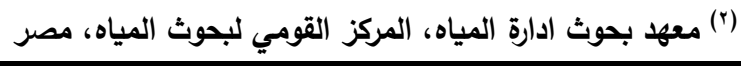

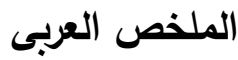

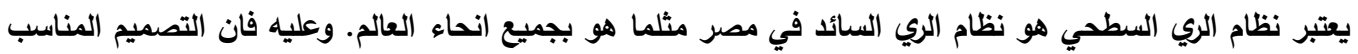

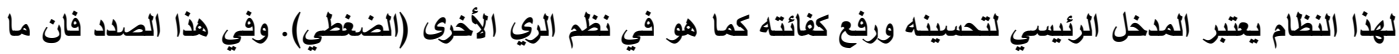

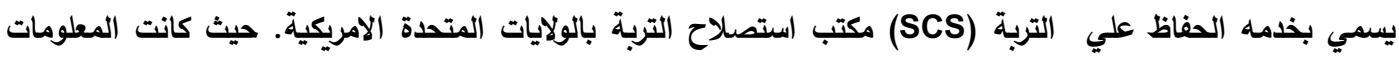

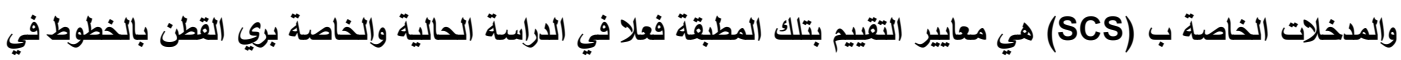

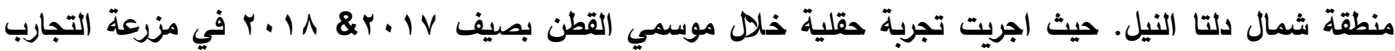

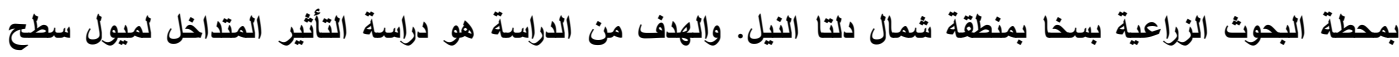

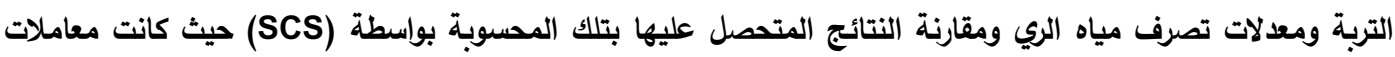

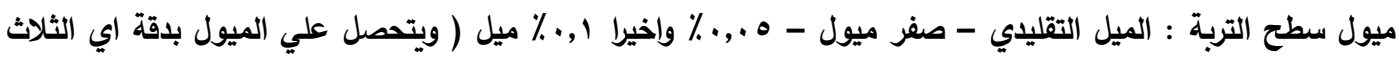

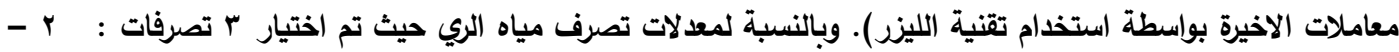

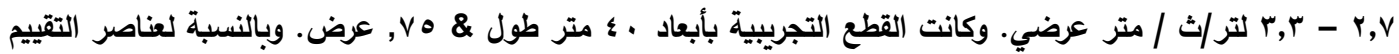

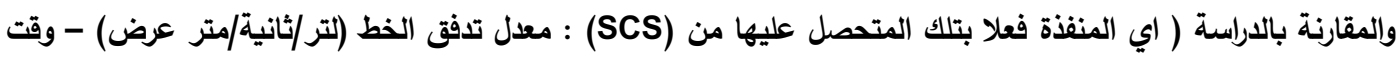

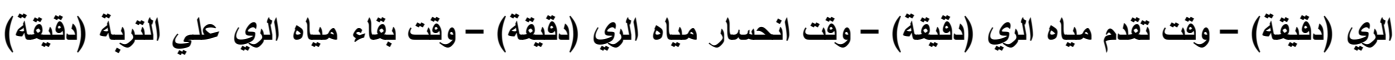

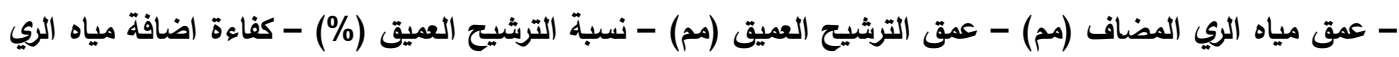

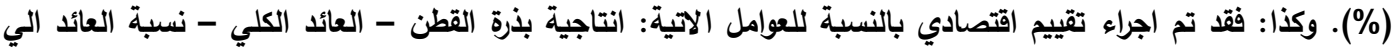

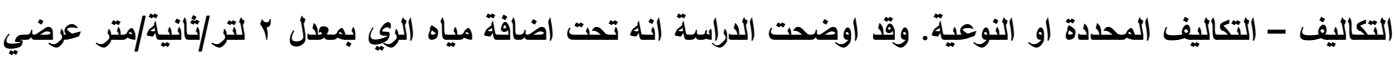

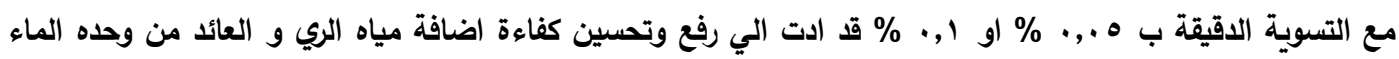
والتربه. وبصفة عامة فان النتائج المتحصل عليها اوضحت وبرهنت علي امكانية استخام بيانات ومقاييس ال (SCS) في المئي تصميم نظام الري السطحي بالخطوط في التربة الطينية بشمال دلتا النيل.

أسماء السادة المحكمين أ.د/ محمد رضوان خليفــه كلية الززاعة - جامعة كفر الثيخ الشيخ

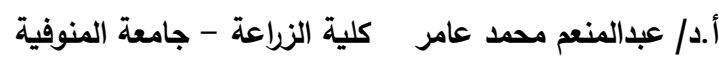

